\title{
Source apportionment of size and time resolved trace elements and organic aerosols from an urban courtyard site in Switzerland
}

\author{
A. Richard ${ }^{1}$, M. F. D. Gianini ${ }^{2}$, C. Mohr ${ }^{1}$, M. Furger ${ }^{1}$, N. Bukowiecki ${ }^{1}$, M. C. Minguillón ${ }^{1,3}$, P. Lienemann ${ }^{4}$, \\ U. Flechsig ${ }^{5}$, K. Appel $^{6}$, P. F. DeCarlo ${ }^{7}$, M. F. Heringa ${ }^{1}$, R. Chirico ${ }^{1,8}$, U. Baltensperger ${ }^{1}$, and A. S. H. Prévôt ${ }^{1}$ \\ ${ }^{1}$ Laboratory of Atmospheric Chemistry, Paul Scherrer Institut, Villigen, Switzerland \\ ${ }^{2}$ Laboratory for Air Pollution and Environmental Technology, Empa, Swiss Federal Laboratories for Materials Science and \\ Technology, Dübendorf, Switzerland \\ ${ }^{3}$ Institute for Environmental Assessment and Water Research (IDAEA), CSIC, Barcelona, Spain \\ ${ }^{4}$ School of Life Sciences and Facility Management, Wädenswil, Switzerland \\ ${ }^{5}$ Swiss Light Source, Paul Scherrer Institut, Villigen, Switzerland \\ ${ }^{6}$ Hamburger Synchrotronstrahlungslabor at Deutsches Elektronen-Synchrotron DESY, a Research Centre of the Helmholtz \\ Association, Hamburg, Germany \\ ${ }^{7}$ AAAS Science and Technology Policy Fellow Hosted at the US EPA, Washington, DC, USA \\ ${ }^{8}$ Italian National Agency for New Technologies, Energy and Sustainable Economic Development (ENEA), FIS-LAS, \\ Frascati, Italy
}

Received: 24 December 2010 - Published in Atmos. Chem. Phys. Discuss.: 2 February 2011

Revised: 2 July 2011 - Accepted: 9 August 2011 - Published: 2 September 2011

\begin{abstract}
Time and size resolved data of trace elements were obtained from measurements with a rotating drum impactor (RDI) and subsequent X-ray fluorescence spectrometry. Trace elements can act as indicators for the identification of sources of particulate matter $<10 \mu \mathrm{m}\left(\mathrm{PM}_{10}\right)$ in ambient air. Receptor modeling was performed with positive matrix factorization (PMF) for trace element data from an urban background site in Zürich, Switzerland. Eight different sources were identified for the three examined size ranges $\left(\mathrm{PM}_{1-0.1}, \mathrm{PM}_{2.5-1}\right.$ and $\left.\mathrm{PM}_{10-2.5}\right)$ : secondary sulfate, wood combustion, fire works, road traffic, mineral dust, de-icing salt, industrial and local anthropogenic activities. The major component was secondary sulfate for the smallest size range; the road traffic factor was found in all three size ranges. This trace element analysis is complemented with data from an Aerodyne high-resolution time-of-flight aerosol mass spectrometer (AMS), assessing the $\mathrm{PM}_{1}$ fraction of organic aerosols. A separate PMF analysis revealed three factors related to three of the sources found with the RDI: oxygenated organic aerosol (OOA, related to inorganic secondary sulfate), hydrocarbon-like organic aerosol (HOA,
\end{abstract}

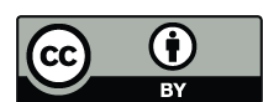

Correspondence to: M. Furger

(markus.furger@psi.ch) related to road traffic) and biomass burning organic aerosol (BBOA), explaining $60 \%, 22 \%$ and $17 \%$ of total measured organics, respectively. Since different compounds are used for the source classification, a higher percentage of the ambient $\mathrm{PM}_{10}$ mass concentration can be apportioned to sources by the combination of both methods.

\section{Introduction}

Ambient particulate matter concentrations have routinely been monitored in Europe. However, measurements are often limited to the mass concentrations of particulate matter with aerodynamic diameter less than $10 \mu \mathrm{m}\left(\mathrm{PM}_{10}\right)$ without information on the elemental composition and the size distribution of the aerosol particles. For the evaluation of the influence of atmospheric aerosols on human health (e.g. the toxicity of a metal when inhaled) and the dispersion via atmospheric transport, knowledge about the composition and size distribution is required. Accumulation mode particles (with diameters around $0.1-1.0 \mu \mathrm{m}$ diameter) deposit slowly within a few days preferentially by precipitation and can therefore be transported over long distances, having effects in regions remote from the source. In addition, particle size (and shape) are key factors that control the extent of penetration into the

Published by Copernicus Publications on behalf of the European Geosciences Union. 
human respiratory system (Lighty et al., 2000). Furthermore, information on the occurrence, strength, spatial distribution and variability of the sources of specific pollutants are the basis of pollution mitigation strategies. Recent papers (Han et al., 2005; Ondov et al., 2006; Querol et al., 2007; Viana et al., 2008; Karanasiou et al., 2009) demonstrate the usefulness of minor and major element measurements in ambient aerosols for the identification of pollution sources. On a mass basis, trace elements represent a minor fraction of the atmospheric aerosol (generally in the order of a few percent), but they can act as specific tracers for several emission sources. Trace metals are found in almost all atmospheric aerosol size fractions of $\mathrm{PM}_{10}$. However, to obtain a more complete picture of the sources present in the atmosphere, additional information besides the one on trace elements is required. The organic component of atmospheric aerosols plays an important role mainly concerning particles with an aerodynamic diameter of less than $1 \mu \mathrm{m}$ : at European continental mid-latitudes, a fraction of $20-50 \%$ of the total fine mode aerosol mass can be attributed to organic matter (Putaud et al., 2004), and about $70 \%$ of the organic carbon mass (suburban summer) is found in fine mode particles (Jaffrezo et al., 2005; Jimenez et al., 2009; Lanz et al., 2010).

To obtain most accurate results in apportionment studies for the identification of ambient pollution sources, time resolved samples are required. For this purpose measurements were performed with a rotating drum impactor (RDI, Bukowiecki et al., 2005, 2009a), having a time resolution in the order of hours. Measurements of the organic components in the fine fraction of ambient aerosols from an aerosol mass spectrometer (AMS) with a time resolution of four minutes were used to complement trace element data from RDI samples and subsequent $\mathrm{X}$-ray fluorescence analysis.

This paper describes a five-week winter campaign at the urban background site at Zürich Kaserne, Switzerland with focus on source apportionment applied to quantitative trace element and organic aerosol data. The campaign was planned in the framework of the European Integrated Project on Aerosol Cloud Climate Air Quality Interactions (EUCAARI, Kulmala et al., 2009), having the aim of investigating the role of aerosol particles on climate and air quality. The activities described here are embedded in the project's activities dealing with regional aerosol source apportionment and attribution of different aerosol mass components in Europe to specific sources. Specific emission patterns were detected with positive matrix factorization (PMF, Paatero and Tapper, 1994) separately for RDI and AMS data. PMF was chosen amongst other source apportionment methods due to the fact that it can be run without initially knowing source compositions and profiles. Receptor models can single out groups of elements with correlated concentration trends and thus enable attribution of these groups to real sources. These models provide three pieces of information: the number of major sources of particulate matter, their profiles and the mass contribution of each source to total particulate matter.

\section{Methods}

\subsection{Description of location and instruments}

The sampling site was located at the well-described urban courtyard site in Zürich Kaserne, Switzerland (Hueglin et al., 2005; Lanz et al., 2007) in the centre of the metropolitan area of Zürich with about half a million inhabitants. The location is considered as an urban background site as far as traffic emissions are concerned and is one of the Swiss long-term monitoring stations. Measurements with the RDI were performed from 28 November 2008 to 5 January 2009 (with a short break from 26 to 28 December), while the AMS was deployed from 1 to 18 December 2008. Aerosol samples taken with the RDI are segregated into three size ranges, the coarse fraction $\mathrm{PM}_{10-2.5}$, an intermediate size range $\mathrm{PM}_{2.5-1}$ and the fine fraction $\mathrm{PM}_{1-0.1}$. Particles larger than $10 \mu \mathrm{m}$ were removed by the inlet ( $\mathrm{PM}_{10}$ impactor) on top of the RDI positioned approx. $2.5 \mathrm{~m}$ above ground. The time resolution was set to $2 \mathrm{~h}$, thus yielding 432 data points in 36 days. The campaign was accomplished with a combination of a series of different instruments (RDI, AMS, $\mathrm{PM}_{1}$ and $\mathrm{PM}_{10}$ daily high-volume samplers with quartz fiber filters, Aethalometer). Measurements of gas-phase pollutants $\left(\mathrm{NO}_{2}, \mathrm{NO}, \mathrm{CO}, \mathrm{SO}_{2}, \mathrm{O}_{3}\right)$ as well as total $\mathrm{PM}_{10}$ with a time resolution of $1 \mathrm{~h}$ (from a tapered element oscillating microbalance, TEOM) and daily gravimetric $\mathrm{PM}_{2.5}$ mass concentrations were provided by the Swiss national air pollution monitoring network (BAFU, 2007), and meteorological data from the MeteoSwiss network were available. Black carbon (BC) was measured with 2-min time resolution with a multiwavelength Aethalometer $(\lambda=370-950 \mathrm{~nm}$, Magee Scientific) equipped with a $1-\mu \mathrm{m}$ cyclone. The $880-\mathrm{nm}$ channel of the Aethalometer was analyzed for BC mass concentrations, which were binned to 2-h intervals. Due to shadowing effects that can occur on the quartz fiber filters with increasing loads of light absorbing particles, a correction as proposed by Weingartner et al. (2003) with an $f$ parameter of 1.2 was applied to the Aethalometer data for the calculation of BC concentrations. Aethalometer data were only available from the beginning of the campaign till 12 December 2008.

Characteristic weather conditions for Swiss winters are low temperatures, persistent clouds with resulting low photochemical activity and thermal inversions. The average temperature was about $2{ }^{\circ} \mathrm{C}$ and the beginning was characterized by more precipitation compared to the end of the campaign. Due to inversion conditions which prevent dilution and mixing of air masses with cleaner air, aerosol mass concentrations can significantly grow. In addition, low temperatures shift the partitioning of nitrate as well as of semi-volatile organics from the gas-phase to the particle phase. This leads to a stronger influence on precipitation and dilution with cleaner air masses compared to the influence of the variation of the sources themselves. Therefore time trends of 
individual sources are typically not separated as clearly in winter as in summer (Lanz et al., 2007, 2008).

\subsection{Analysis methods}

The elemental analysis of RDI data was carried out by Synchrotron radiation induced $\mathrm{X}$-ray fluorescence spectrometry (SR-XRF) at two different beamlines to detect the $\mathrm{K} \alpha$-lines of 23 elements (Al, Si, P, S, Cl, K, Ca, Ti, V, Cr, Mn, Fe, $\mathrm{Co}, \mathrm{Ni}, \mathrm{Cu}, \mathrm{Zn}, \mathrm{Sr}, \mathrm{Zr}, \mathrm{Mo}, \mathrm{Sn}, \mathrm{Sb}, \mathrm{Ba}$ and the L $\alpha$-line of $\mathrm{Pb}$ ). Elements with $Z=13-24(\mathrm{Al}-\mathrm{Cr}$ ) were measured at the X05DA beamline at the Swiss light source (SLS) at PSI (Flechsig et al., 2009), while elements with $Z=25-82$ $(\mathrm{Mn}-\mathrm{Pb})$ were detected at the beamline L, HASYLAB at DESY. Raw counts per element were calibrated with a sensitivity curve [counts ${ }^{-1} \mu \mathrm{g} \mathrm{m}^{-3}$ ] measured in the same geometry on customized external reference standards on thin films described elsewhere (Fittschen et al., 2006, 2010; Richard et al., 2010). Details of the methodology can be found in Bukowiecki et al. (2008, 2009a).

Two high-volume samplers (Digitel, Aerosol Sampler DHA-80) with $\mathrm{PM}_{1}$ and $\mathrm{PM}_{10}$ inlets were used to collect 24$\mathrm{h}$ filter samples in the period from 1 to 17 December 2008 (daily samples for $\mathrm{PM}_{1}$ and every second day for $\mathrm{PM}_{10}$ ). A fraction of the quartz micro-fiber filter was acid digested and subsequently analyzed by inductively coupled plasma optical emission spectrometry (ICP-OES) and mass spectrometry (ICP-MS, see details of the method in Querol et al., 2008) for the determination of major and minor elements. Ambient mass concentrations of the following species are available: $\mathrm{Na}, \mathrm{Mg}, \mathrm{Al}, \mathrm{S}, \mathrm{Cl}, \mathrm{K}, \mathrm{Ca}, \mathrm{Ti}, \mathrm{V}, \mathrm{Cr}, \mathrm{Mn}, \mathrm{Fe}, \mathrm{Co}, \mathrm{Cu}, \mathrm{Zn}$, As, $\mathrm{Se}, \mathrm{Rb}, \mathrm{Y}, \mathrm{Cd}, \mathrm{Sn}, \mathrm{Ce}, \mathrm{Sb}, \mathrm{Pb}$ as well as $\mathrm{SO}_{4}^{-2}, \mathrm{NO}_{3}^{-}$and $\mathrm{NH}_{4}^{+}$. In the framework of an additional long-term project (Gianini et al., 2011), filter samples were taken on every fourth day from August 2008 to July 2009, matching this study's sampling period from 2 December 2008 to 3 January 2009.

An Aerodyne high-resolution time-of-flight aerosol mass spectrometer (AMS, DeCarlo et al., 2006) was deployed from 1 December 2008 till 18 December 2008 to characterize non-refractory submicron aerosol components. Data of organic fragments with a time resolution of four minutes were obtained from the aerosol mass spectra, assuming a collection efficiency of 1 . The AMS was run in two modes, the $\mathrm{V}$ and $\mathrm{W}$ mode, but results presented here are taken in the V-mode, which has lower resolution but higher sensitivity. A detailed description of the AMS data analysis principles can be found in Canagaratna et al. (2007).

\subsection{Source apportionment method}

Positive matrix factorization (PMF, Paatero and Tapper, 1994; Paatero, 1997) is a multivariate factor analysis tool which differentiates the sample matrix $\mathbf{X}$ of ambient mass concentrations into two matrices - factor contributions $\mathbf{G}$ and factor profiles $\mathbf{F}$ - for which the represented source types have to be interpreted. The objective of multivariate receptor modeling is to obtain $p$ independent factors, representing $p$ different sources of emissions as well as their elemental composition and the amount that they contribute to the total signal. There are some fundamental physical constraints that must be obeyed, for example that the original data must be reproduced by the model. The predicted source compositions and the contributions must be non-negative since a source cannot have negative elemental contributions of an element or emit negative mass. The sum of the predicted elemental mass contributions for each source must be less than or equal to the total measured mass for each element. The corresponding two-way factor model can be expressed through the following equation:

$\mathbf{X}=\mathbf{G F}+\mathbf{E}$

or

$x_{i j}=\sum_{k=1}^{p} g_{i k} f_{k j}+e_{i j}$

with $i=1, \ldots, n ; j=1, \ldots, m ; k=1, \ldots, p, \mathbf{X}$ is the $n \times m$ data matrix consisting of $n$ rows of $n$ samples and $m$ columns containing the $m$ detected species, $\mathbf{G}$ is a $n \times p$ matrix of source contributions and $\mathbf{F}$ is a $p \times m$ matrix of source profiles. The remaining unmodeled part of the data is represented by the residual matrix $\mathbf{E}$. The values $g_{i k}$ and $f_{k j}$ (required to be non-negative) are adjusted until a minimum for the objective function $Q$, the sum of squares of the ratio of the residuals and the user defined uncertainty matrix $\sigma$ (Eqs. 7 and 8) for a given number of factors $p$ is found:

$Q=\sum_{i=1}^{n} \sum_{j=1}^{m}\left(\frac{x_{i j}-g_{i k} f_{k j}}{\sigma_{i j}}\right)^{2}$

The theoretical $Q\left(Q_{\exp }\right)$ can be approximated as

$Q_{\exp }=n m-p(n+m)$

It is the goal to find solutions with a minimum for $Q / Q_{\exp }$. Hence it is tempting to examine the resulting and estimated $Q$ value as a function of $p$ to determine the number of factors to retain, but this approach can be misleading if the data point uncertainties are not well determined. Another useful indicator can be the plot of scaled residuals, the ratio of the PMF-modeled residual $e_{i j}$ to the input uncertainty $\sigma_{i j}$ :

$\frac{e_{i j}}{\sigma_{i j}}=\frac{x_{i j}-\sum_{k=1}^{p} g_{i k} f_{k j}}{\sigma_{i j}}$

The examination of scaled residuals can help to ensure that the appropriate number of factors was chosen. A reasonable solution should have Gaussian-like scaled residuals distributions mostly between -3 and +3 . If the value of the scaled 
residual for a data value is larger than the outlier threshold distance $\alpha$ (set to 4 ), it is defined as an outlier:

$\left|\frac{e_{i j}}{\sigma_{i j}}\right|>\alpha=4$

PMF was always run in the robust mode, where outlier values are excluded to decrease the influence of extreme values on the PMF solution.

\subsection{Data preparation}

Data values with unusually high variability can be downweighted in PMF by attribution of a larger uncertainty (Paatero and Hopke, 2003). This provides on the one hand a convenient measure to include these high variability elements and those with a high intrinsic uncertainty into the calculation without distorting the result inappropriately. On the other hand it requires a thorough calculation of measurement uncertainties to prevent an undesired alteration of the result. Before starting the PMF algorithm, data were inspected with respect to reliability (outliers and extreme values) and measurement uncertainties.

For the RDI-PMF calculations, missing values (i.e. when the fit for SR-XRF spectra yielded no reasonable result) were substituted by the mean of adjacent values rather than excluding the whole sample completely from the data set (Huang et al., 1999). An uncertainty of $10 \%$ of the overall maximum concentration of this species was attributed to each replaced value. Elements with a large number $(\geq 20 \%)$ of replaced values were completely excluded from the data set. Whenever a single value was below the detection limit of its species, the value was replaced with half of the minimal detection limit (MDL/2) and the corresponding uncertainty value was replaced with 5/6 - MDL (Polissar et al., 1998). Elements retained in the final data set were those with more than $50 \%$ of values above detection limit and not more than $20 \%$ of replaced missing values as reported in Table 1.

AMS-PMF calculations were done with a total of 269 species containing reliable information on the organic aerosol phase (mass-to-charge ratios, $m / z$ 12-13, 15-18, 24$31,37-38,41-45,48-148,150-181,185$ and 187-300). The other $\mathrm{m} / \mathrm{z}$ 's were excluded due to dominant contributions of the air signals (e.g. $m / z 32$ and 40 for $\mathrm{O}_{2}$ and Ar, respectively), inorganic species (e.g. $\mathrm{m} / \mathrm{z}, 39$ and 46 for $\mathrm{K}$ and nitrate, respectively), high background levels (e.g. $m / z$ 186) or lack of plausible organic fragments (e.g. $m / z<12$ ). More details on the interpretation of organic fragments can be found in Allan et al. (2004) and Zhang et al. (2005).

The uncertainty matrix $\sigma_{i j, \text { RDI }}$ of RDI data for the source apportionment calculations was obtained as follows:

$\sigma_{i j, \mathrm{RDI}}=s_{i j}+\frac{\mathrm{MDL}_{\mathrm{j}}}{3}$

where $s_{i j}$ is the systematic analytical uncertainty introduced through sampling and analysis methods. Analytical uncer-
Table 1. List of elements finally retained in the data set (indicated with an "x") having more than $50 \%$ of values above detection limit and not more than $20 \%$ of replaced missing values. Elements marked with an asterisk $\left({ }^{*}\right)$ had a signal-to-noise ratio of $S / N<2$ and were thus included as weak variables.

\begin{tabular}{lccc}
\hline Element & PM $_{10-2.5}$ & $\mathrm{PM}_{2.5-1}$ & $\mathrm{PM}_{1-0.1}$ \\
\hline $\mathrm{Al}$ & $\mathrm{x}$ & - & - \\
$\mathrm{Si}$ & $\mathrm{x}$ & $\mathrm{x}$ & $\mathrm{x}^{*}$ \\
$\mathrm{P}$ & - & $\mathrm{x}$ & $\mathrm{x}$ \\
$\mathrm{S}$ & $\mathrm{x}$ & $\mathrm{x}$ & $\mathrm{x}$ \\
$\mathrm{Cl}$ & $\mathrm{x}$ & $\mathrm{x}$ & - \\
$\mathrm{K}$ & $\mathrm{x}$ & $\mathrm{x}^{*}$ & $\mathrm{x}$ \\
$\mathrm{Ca}$ & $\mathrm{x}$ & $\mathrm{x}$ & $\mathrm{x}^{*}$ \\
$\mathrm{Ti}$ & $\mathrm{x}$ & $\mathrm{x}$ & $\mathrm{x}$ \\
$\mathrm{V}$ & - & - & $\mathrm{x}$ \\
$\mathrm{Cr}$ & - & $\mathrm{x}$ & - \\
$\mathrm{Mn}$ & $\mathrm{x}$ & $\mathrm{x}$ & $\mathrm{x}$ \\
$\mathrm{Fe}$ & $\mathrm{x}$ & $\mathrm{x}$ & $\mathrm{x}$ \\
$\mathrm{Co}$ & $\mathrm{x}$ & $\mathrm{x}$ & - \\
$\mathrm{Ni}$ & - & $\mathrm{x}$ & $\mathrm{x}$ \\
$\mathrm{Cu}$ & $\mathrm{x}$ & $\mathrm{x}$ & $\mathrm{x}$ \\
$\mathrm{Zn}$ & $\mathrm{x}$ & $\mathrm{x}$ & $\mathrm{x}$ \\
$\mathrm{Sr}$ & $\mathrm{x}$ & $\mathrm{x}$ & $\mathrm{x}$ \\
$\mathrm{Zr}$ & $\mathrm{x}$ & $\mathrm{x}$ & $\mathrm{x}$ \\
$\mathrm{Mo}$ & $\mathrm{x}$ & $\mathrm{x}$ & $\mathrm{x}$ \\
$\mathrm{Sn}$ & $\mathrm{x}$ & $\mathrm{x}$ & $\mathrm{x}$ \\
$\mathrm{Sb}$ & $\mathrm{x}$ & $\mathrm{x}$ & $\mathrm{x}$ \\
$\mathrm{Ba}$ & $\mathrm{x}$ & $\mathrm{x}$ & $\mathrm{x}$ \\
$\mathrm{Pb}$ & - & $\mathrm{x}$ & $\mathrm{x}$ \\
\hline
\end{tabular}

tainties were calculated under the assumption that the extrapolation from the lower beam size to the larger total area of the RDI-bar introduces an estimated uncertainty of $20 \%$ of the area due to a not perfectly homogeneous distribution of sample material on the film. Also the not perfectly constant flow of the impactor pump and the uncertainty of a linear regression used for the absolute calibration enter into the uncertainty calculation with a relative uncertainty of $5 \%$ each. Gaussian uncertainty propagation was performed for these three terms on the basis of the calibration formula introduced in Richard et al. (2010). During the analysis different methods to calculate the uncertainty matrix $\sigma_{i j}$ for example as compiled in Reff et al. (2007) were tested and Eq. (7) was found to give the most stable results. Different ways of calculating the measurement uncertainties and testing the influence on the final results helped in obtaining a robust and feasible solution. However, the influence of the method of uncertainty calculation compared to the influence of the choice of elements on the final result was low.

The uncertainty estimate $\sigma_{j, \mathrm{AMS}}$ for a given AMS signal in $[\mathrm{Hz}]$ is defined as:

$\sigma_{j, \mathrm{AMS}}=\alpha \sqrt{\frac{\left(I_{j \mathrm{o}}+I_{j \mathrm{~b}}\right)}{t_{\mathrm{S}}}}$ 
Table 2. Settings chosen for the PMF calculations, for each RDI size range $\mathrm{PM}_{10-2.5}, \mathrm{PM}_{2.5-1}$ and $\mathrm{PM}_{1-0.1}$ as well as for AMSPMF. The FPEAK values indicate a rotation of the solution, the value of the extra modeling uncertainty is listed in the column named m.e., which can be specified for each calculation by the constant $C 3$ and EM is the error model, which was kept constant for all calculations (Eq. 10). Elements and mass fragments defined as weak variables (resulting in tripling of the user-specified uncertainty) are given in the last column.

\begin{tabular}{lcccl}
\hline fraction & FPEAK & m.e. & EM & weak var. \\
\hline $\mathrm{PM}_{10-2.5}$ & -1 & $5 \%$ & -14 & $\mathrm{Al}, \mathrm{Ni}, \mathrm{Pb}$ \\
$\mathrm{PM}_{2.5-1}$ & 0 & $5 \%$ & -14 & $\mathrm{~K}, \mathrm{Cr}, \mathrm{Ni}, \mathrm{Pb}$ \\
$\mathrm{PM}_{1-0.1}$ & 0 & $5 \%$ & -14 & $\mathrm{Si}, \mathrm{Ca}$ \\
$\mathrm{AMS}$ & -0.4 & $0 \%$ & -12 & $150,167,207$ \\
& & & & $208,280-283$ \\
\hline
\end{tabular}

and was calculated from the ion signals of $m / z_{j}, I_{j \mathrm{o}}$ and $I_{j \mathrm{~b}}$ (the ion signal at blocked aerosol beam $I_{j \mathrm{~b}}$ is subtracted from the open beam signal $I_{j \mathrm{o}}$ in order to calculate the total AMS signal), sampling time $t_{\mathrm{S}}$ and a statistical distribution factor $\alpha$ and was then transferred into organicequivalent concentrations (org-eq. $\mu \mathrm{g} \mathrm{m}^{-3}$ ) using the ToFAMS Analysis toolkit version 1.47 based on the work of Allan et al. (2003) (http://cires.colorado.edu/jimenez-group/ ToFAMSResources/ToFSoftware/index.html).

Furthermore, the data were analyzed for the signal to noise ratio $S / N$ :

$$
\left(\frac{S}{N}\right)_{j}=\sqrt{\frac{\sum_{i=1}^{n}\left(x_{i j}-\sigma_{i j}\right)^{2}}{\sum_{i=1}^{n} \sigma_{i j}^{2}}}
$$

with the user-defined error matrix $\sigma$ (Eqs. 7 and 8). Variables with $0.2<S / N<2$ were defined as weak variables and were downweighted by tripling of the user-provided uncertainty. Variables with $S / N<0.2$ were called "bad" and were excluded from the analysis. A number of elements and $\mathrm{m} / \mathrm{z}$ 's were categorized as weak variables as reported in Tables 1 and 2. Downweighting of the $m / z$ 's proportional to $m / z 44$ as suggested by Ulbrich et al. (2009) did not lead to reasonable results as it complicated the separation of different sources from each other. This might be due to meteorological variability and the resulting similarity of time series of different factors and therefore the small amount of a priori information included in $m / z 44$ proved to be helpful for a better separation of sources (Mohr et al., 2011).

In this study two programs to solve Eq. (2) were tested with the same RDI input data: PMF2 (version 4.2, Paatero, 2004) and the Multilinear Engine (ME-2, Paatero, 1999, PMF2-equivalent script). Good agreement was found for calculations with ME-2 and PMF2 and exemplary results are shown in the supplementary material (Fig. S1). Since the obtained results were almost identical, only the solutions produced with the PMF2 for RDI and AMS data are discussed in Sect. 3.2. For calculations with AMS data the PMF Evaluation Toolkit (PET, version 2.03A), developed at the University of Colorado and presented by Ulbrich et al. (2009) was employed. The PMF2 algorithm was used with error model $\mathrm{EM}=-14$ for RDI data, which is commonly used in many environmental applications and $\mathrm{EM}=-12$ for AMS data. The difference of the two models is that the uncertainties are calculated once on the basis of the data matrix $\mathbf{X}$ for $\mathrm{EM}=-12\left(d=\left|x_{i j}\right|\right.$ in Eq. 10), while for $\mathrm{EM}=-14$ the uncertainty is recalculated after each iteration using the maximum of the input value $\mathbf{X}$ or the modeled value $\mathbf{Y}=\mathbf{G F}$ $\left(d=\max \left(\left|x_{i j}\right|,\left|y_{i j}\right|\right)\right)$ :

$s_{i j}=C 1_{i j}+C 2_{i j} \sqrt{|d|}+C 3_{i j}|d|$

with error constants $C 1$ (constant uncertainty value, not used because the user defined measurement uncertainties were read in), $C 2$ (only used in Poisson like situations) and $C 3$ (0-0.25 for environmental problems). This extra modeling uncertainty quantified by the constant $C 3$ can be chosen for each run and will reduce the ratio of $Q / Q_{\exp }$, to account for variability of source profiles and chemical transformations in the atmosphere. It was varied between 0-20\% and finally set to the values reported in Table 2 .

The determination of the right number of factors and the interpretation of the factor profiles with respect to a realistic physical meaning form the most critical part in the analysis since personal interaction is involved. Inclusion and exclusion of species can significantly influence the PMF model results; this was also experienced by Huang et al. (1999) and therefore many different combinations of data sets were tested. The result of these tests was a less clear separation of sources, or elements being mixed into factor profiles that do not match to the emission source. To explore rotations of the solutions for a given number of factors, the parameter FPEAK can be varied. For the RDI analysis, FPEAK values in the interval $[-1.2,1.2]$ with a step width of 0.1 were tested. For the AMS analysis the FPEAK parameter was varied from -0.6 to 0.6 and the finally chosen values for the most meaningful solution are listed in Table 2.

\section{Results}

\subsection{Trace element data from RDI and high-volume samplers}

Trace element mass concentrations obtained by RDI measurements were compared to several daily filter measurements. Accordingly, the RDI data were binned into 24-h intervals by calculating the mean of 12 data points and all three RDI-stages were summed up for a comparison to $\mathrm{PM}_{10}$, while $\mathrm{PM}_{1}$ filter values were compared to $\mathrm{PM}_{1-0.1} \mathrm{RDI}$ values. Figures 1 and S2 display the overall good comparison of filter and RDI data for $\mathrm{PM}_{10}$ and $\mathrm{PM}_{1}$, respectively. Measurement uncertainties of the RDI data are the analytical 
Table 3. Mean values, minimal detection limits and relative uncertainties (in \%) for all three size ranges, $\mathrm{PM}_{10-2.5}, \mathrm{PM}_{2.5-1}$ and $\mathrm{PM}_{1-0.1}$ in $\mathrm{ng} \mathrm{m}^{-3}$.

\begin{tabular}{|c|c|c|c|c|c|c|c|c|c|}
\hline Element & $\begin{array}{c}\mathrm{PM}_{10-2.5} \\
\text { mean } \\
\left(\mathrm{ng} \mathrm{m}^{-3}\right)\end{array}$ & $\begin{array}{c}\mathrm{MDL} \\
\left(\mathrm{ng} \mathrm{m}^{-3}\right)\end{array}$ & $\begin{array}{l}\text { rel. unc. } \\
(\%)\end{array}$ & $\begin{array}{c}\mathrm{PM}_{2.5-1} \\
\text { mean } \\
\left(\mathrm{ng} \mathrm{m}^{-3}\right)\end{array}$ & $\begin{array}{c}\mathrm{MDL} \\
\left(\mathrm{ng} \mathrm{m}^{-3}\right)\end{array}$ & $\begin{array}{l}\text { rel. unc. } \\
\qquad(\%)\end{array}$ & $\begin{array}{c}\mathrm{PM}_{1-0.1} \\
\text { mean } \\
\left(\mathrm{ng} \mathrm{m}^{-3}\right)\end{array}$ & $\begin{array}{c}\mathrm{MDL} \\
\left(\mathrm{ng} \mathrm{m}^{-3}\right)\end{array}$ & $\begin{array}{l}\text { rel. unc. } \\
\qquad(\%)\end{array}$ \\
\hline $\mathrm{Al}$ & 64.2 & 12.35 & 28 & - & - & - & - & - & - \\
\hline $\mathrm{Si}$ & 145.2 & 15.57 & 26 & 54.6 & 7.36 & 26 & 11.1 & 3.6 & 42 \\
\hline $\mathrm{P}$ & - & - & - & 25.1 & 6.71 & 43 & 26.1 & 3.12 & 30 \\
\hline$S$ & 363.8 & 18.91 & 23 & 864.8 & 8.85 & 21 & 1165.7 & 3.83 & 21 \\
\hline $\mathrm{Cl}$ & 605.7 & 9.25 & 22 & 50.8 & 4.38 & 43 & - & - & - \\
\hline $\mathrm{K}$ & 245.4 & 11.57 & 23 & 333.1 & 5.62 & 22 & 739.7 & 1.89 & 21 \\
\hline $\mathrm{Ca}$ & 104.8 & 0.78 & 21 & 30.3 & 0.38 & 21 & 2.3 & 0.11 & 23 \\
\hline $\mathrm{Ti}$ & 4 & 0.48 & 25 & 1.8 & 0.24 & 25 & 0.7 & 0.05 & 37 \\
\hline V & - & - & - & - & - & - & 0.4 & 0.07 & 66 \\
\hline $\mathrm{Cr}$ & - & - & - & 0.9 & 0.13 & 25 & - & - & - \\
\hline $\mathrm{Mn}$ & 3.5 & 1.3 & 35 & 1.6 & 0.6 & 35 & 0.7 & 0.27 & 38 \\
\hline $\mathrm{Fe}$ & 237.7 & 1.03 & 21 & 121.3 & 0.48 & 21 & 30.7 & 0.21 & 21 \\
\hline $\mathrm{Co}$ & 1.7 & 0.82 & 42 & 0.9 & 0.37 & 41 & - & - & - \\
\hline $\mathrm{Ni}$ & - & - & - & 0.4 & 0.29 & 62 & 0.2 & 0.13 & 55 \\
\hline $\mathrm{Cu}$ & 16.9 & 0.56 & 22 & 8.8 & 0.26 & 22 & 2.4 & 0.12 & 22 \\
\hline $\mathrm{Zn}$ & 5.9 & 0.48 & 24 & 5.7 & 0.22 & 22 & 8.7 & 0.1 & 21 \\
\hline $\mathrm{Sr}$ & 0.5 & 0.13 & 37 & 0.6 & 0.06 & 33 & 0.4 & 0.03 & 48 \\
\hline $\mathrm{Zr}$ & 0.8 & 0.11 & 25 & 0.4 & 0.05 & 25 & 0.1 & 0.02 & 28 \\
\hline Mo & 0.8 & 0.09 & 26 & 0.4 & 0.04 & 24 & 0.1 & 0.02 & 26 \\
\hline $\mathrm{Sn}$ & 1.4 & 0.13 & 24 & 0.8 & 0.06 & 23 & 0.4 & 0.03 & 23 \\
\hline $\mathrm{Sb}$ & 1.4 & 0.15 & 24 & 0.8 & 0.07 & 24 & 0.3 & 0.03 & 24 \\
\hline $\mathrm{Ba}$ & 3 & 0.44 & 26 & 2.4 & 0.2 & 25 & 1.3 & 0.09 & 32 \\
\hline $\mathrm{Pb}$ & - & - & - & 3.6 & 0.3 & 31 & 10.6 & 0.14 & 22 \\
\hline
\end{tabular}

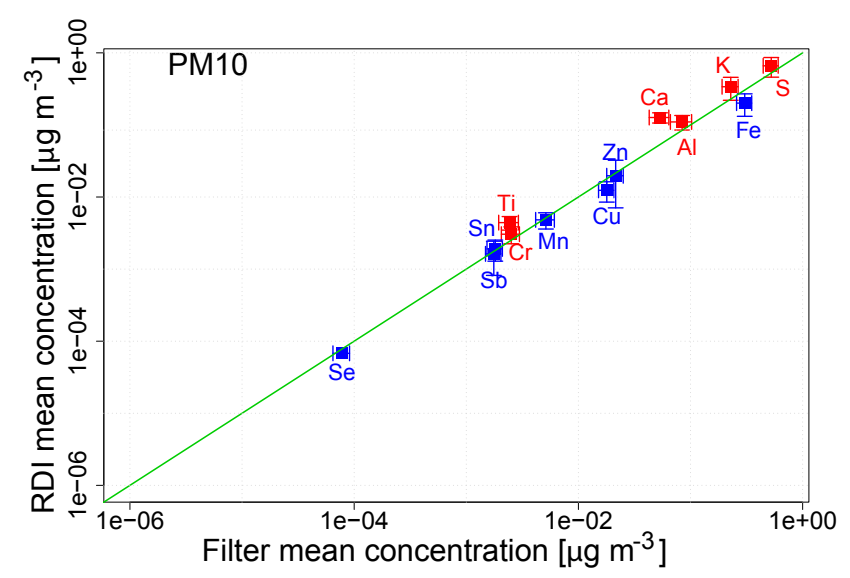

Fig. 1. Comparison of the mean values of nine $\mathrm{PM}_{10}$ filter samples from high-volume samplers and RDI data. Elements measured at the X05DA beamline at SLS are displayed in red, elements measured at HASYLAB L beamline are displayed in blue.

uncertainties $\left(s_{i j}\right.$, Eq. 7) and are calculated with Gaussian error propagation for the calculation of mean values, the uncertainties of filter data were calculated following the method of Escrig et al. (2009). A comparison to the values of the additional long-term campaign is shown in Fig. S3 and shows reasonable agreement. Averaged mass concentrations of elements detected by both methods for days of simultaneous measurements compared very well: the sum of mass concentrations of the analyzed elements of $\mathrm{PM}_{1}$ filter data were equal to $0.64 \mu \mathrm{g} \mathrm{m}^{-3}$ while the $\mathrm{PM}_{1-0.1}$ RDI data summed up to $0.68 \mu \mathrm{g} \mathrm{m}^{-3}$ (this comparison includes the following elements: P, S, K, Ca, Ti, V, Cr, Mn, Fe, Co, Ni, Cu, Zn, Rb, $\mathrm{Sr}, \mathrm{Zr}, \mathrm{Sn}, \mathrm{Sb}, \mathrm{Ba}$ and $\mathrm{Pb}$ ). Average mass concentrations of $\mathrm{PM}_{10}$ filter data amounted to $2.7 \mu \mathrm{g} \mathrm{m}^{-3}$ and the average mass concentrations of $\mathrm{PM}_{10-0.1} \mathrm{RDI}$ data were equal to $2.55 \mu \mathrm{g} \mathrm{m}^{-3}$, including the same elements as for $\mathrm{PM}_{1}$ as well as $\mathrm{Cl}$ and Mo. Table 3 gives an overview on mean concentrations, absolute uncertainties and minimal detection limits. For comparison, average mass concentrations for total $\mathrm{PM}_{10}$ and $\mathrm{PM}_{2.5}$ during the campaign were 25 and $21 \mu \mathrm{g} \mathrm{m}^{-3}$, respectively.

Due to the high time resolution of RDI data it was possible to detect average diurnal variations of elemental mass concentrations, which are displayed in Figs. 2 and S4 as an example for $\mathrm{PM}_{10-2.5}$ and $\mathrm{PM}_{1-0.1}$. Each 2-h interval in the box plots contains 36 data points. $\mathrm{Fe}, \mathrm{Cu}, \mathrm{Sn}$ and $\mathrm{Sb}$ show a related pattern to the rush-hour times of increased traffic activities. Since the measurement location is an urban background site, road traffic related particles reach the sampling site slightly later than the actual emissions occur. 


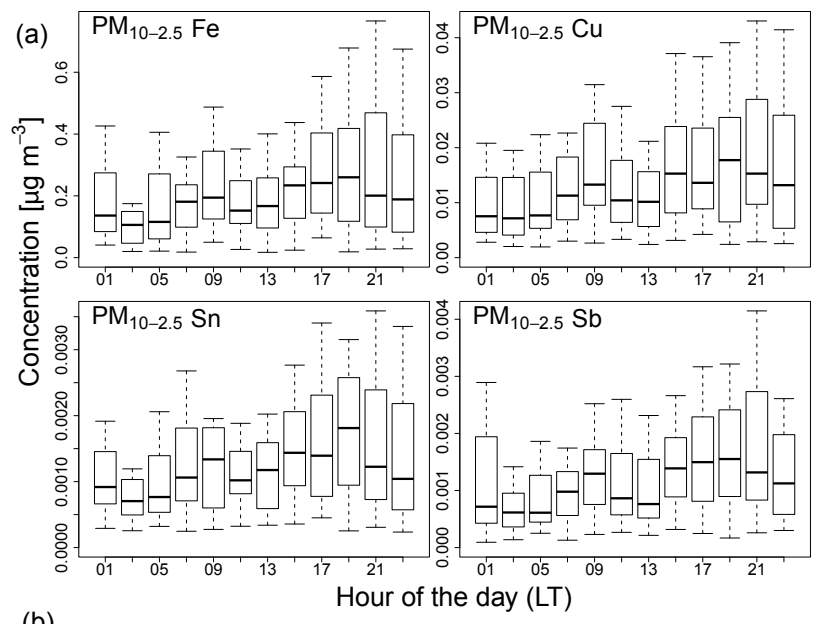

(1)

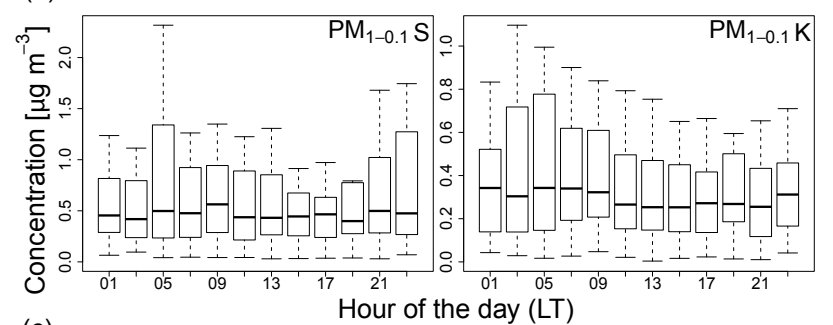

(c)

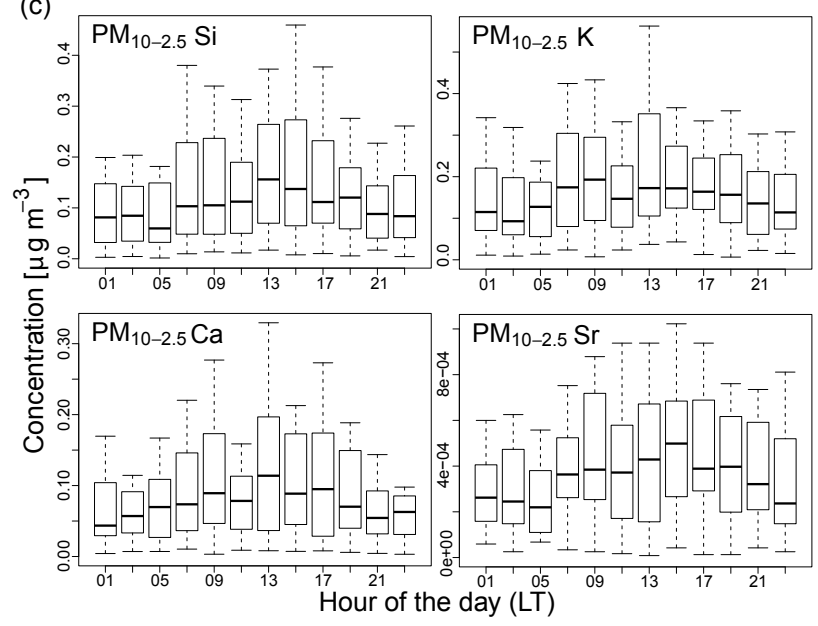

Fig. 2. Average diurnal variations of $\mathrm{Fe}, \mathrm{Cu}, \mathrm{Sn}$ and $\mathrm{Sb}$ in the largest size range, $\mathrm{PM}_{10-2.5}$, (a) and $\mathrm{S}$ and $\mathrm{K}$ in the smallest size range $\mathrm{PM}_{1-0.1}$, (b). Coarse mode traffic related elements show a related pattern to morning and evening rush hours, whereas fine mode $\mathrm{S}$ and $\mathrm{K}$ show no clear diurnal variation. Panel (c) shows average diurnal variations of crustal elements $\mathrm{Si}, \mathrm{K}, \mathrm{Ca}$ and $\mathrm{Sr}$ in the largest size range, $\mathrm{PM}_{10-2.5}$. Elevated mass concentrations of mineral dust are found during midday and the variations are not as strong as for traffic related elements. Data during fireworks at New Years Eve from 31 December 2008 15:00 LT to 1 January 2009 05:00 LT are excluded.

Diurnal variations are also influenced by atmospheric mixing and dilution and can therefore differ from the mere traffic pattern. No clear diurnal variations were found for fine mode $\mathrm{S}$ and $\mathrm{K}$, indicating a regional rather than a local ori-
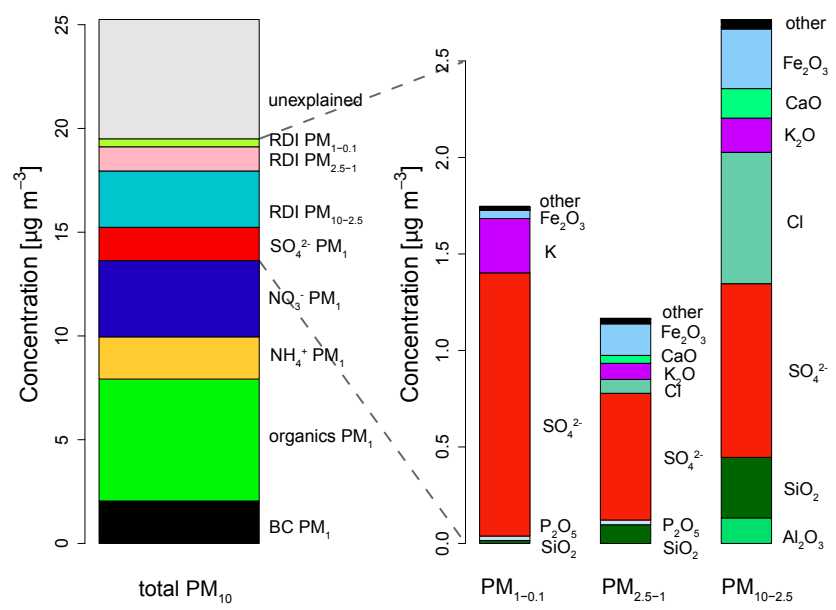

Fig. 3. Bar charts showing the average composition of total measured $\mathrm{PM}_{10}$ in the period of simultaneous RDI, AMS and BC $\left(\mathrm{PM}_{1}\right)$ measurements: the left side shows all identified components of the total $\mathrm{PM}_{10}$ mass concentration, leaving an unexplained fraction of about $25 \%$. Shown are $\mathrm{BC}$ (Aethalometer, $\mathrm{PM}_{1}$ ), the components identified by the AMS (organics, $\mathrm{NH}_{4}^{+}, \mathrm{NO}_{3}^{-}, \mathrm{SO}_{4}^{2-}$ ) and the sum of trace elements for each size range (masses are extrapolated to the corresponding oxides, except for $\mathrm{K}$ in the fine mode and $\mathrm{Cl}$ in the coarse mode). The right side shows the elemental composition, extrapolated to the oxides, for the three size ranges $\left(\mathrm{PM}_{10-2.5}\right.$, $\mathrm{PM}_{2.5-1}$ and $\left.\mathrm{PM}_{1-0.1}\right)$ as determined by the RDI and $\mathrm{SO}_{4}^{2-}$ as determined by the AMS for $\mathrm{PM}_{1-0.1}$.

gin. Daytime mass concentrations of $\mathrm{Si}, \mathrm{K}, \mathrm{Ca}$ and $\mathrm{Sr}$ in $\mathrm{PM}_{10-2.5}$ exceeded night-time mass concentrations without specific daily pattern and suggest that these mineral dust elements are resuspended through daytime activities close and nearby Zürich Kaserne. Figure 3 shows the relative composition of measured compounds and the fraction they contribute to total measured $\mathrm{PM}_{10}$ mass (in the period of simultaneous RDI, AMS and BC measurements). The right side shows the relative composition of the measured trace elements, extrapolated to their oxides (except for $\mathrm{K}$ in the fine mode and $\mathrm{Cl}$ in the coarse mode, which are assumed to be present as water soluble salts). In the largest size range $\mathrm{Cl}$ (presumably from de-icing salt) and crustal elements $(\mathrm{Fe}, \mathrm{K}, \mathrm{Ca}, \mathrm{Si}$, $\mathrm{Al}$ ) contribute the largest amounts. Sulfur (not shown because of redundancy with $\mathrm{SO}_{4}^{2-}$ ) and potassium account for the highest contributions in the fine mode, whereas contributions from metals are negligible. The intermediate size range represents a mixture of these characteristics: $\mathrm{K}$ also contributes the highest amounts to the total mass concentration, but crustal elements like $\mathrm{Fe}, \mathrm{Ca}, \mathrm{Si}$, as well as $\mathrm{Cl}$ are also observed. Note that for all comparative figures (Figs. 2, 3, S4 and S5) the period from 31 December 2008 15:00 LT to 1 January 2009 05:00 LT is excluded to avoid distortion through unusually high emissions of some elements during fireworks at New Year's Eve (NYE). 


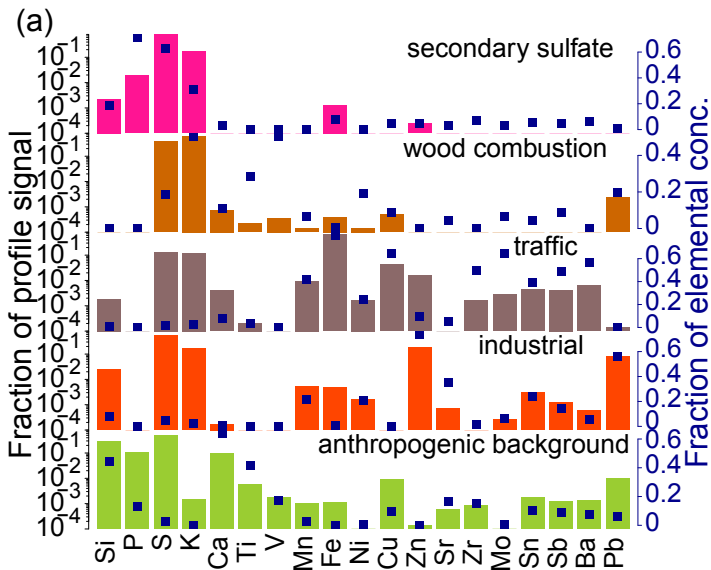

(c)

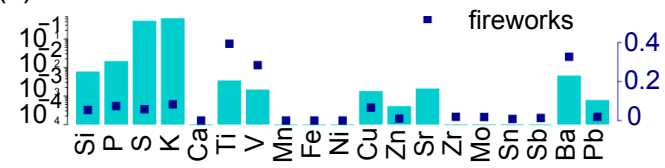

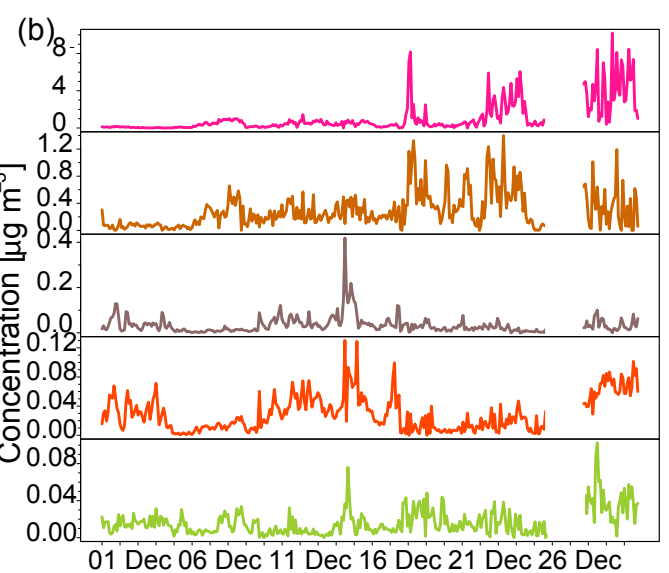

(d)

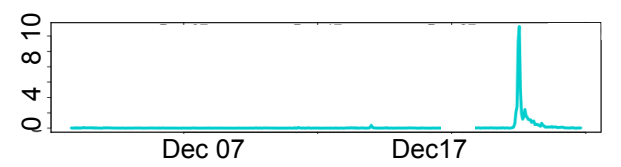

Fig. 4. PMF results for $\mathrm{PM}_{1-0.1}$. (a) factor profiles, from top to bottom: secondary sulfate, wood combustion, road traffic, industrial and local anthropogenic background. The solid bars (left $y$-axis) represent the amount of each species apportioned to the factor and the blue squares (right $y$-axis) represent the fraction of the total of each species. (b) corresponding time series. (c and d) profile and time series of the fireworks factor (full data set, including NYE data).

(a)

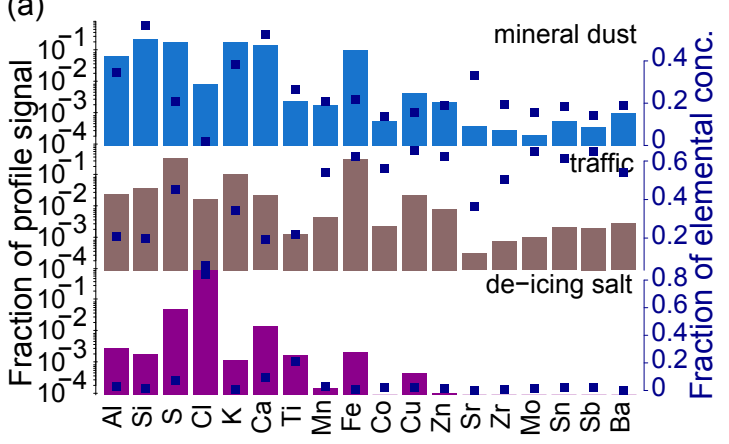

(b)

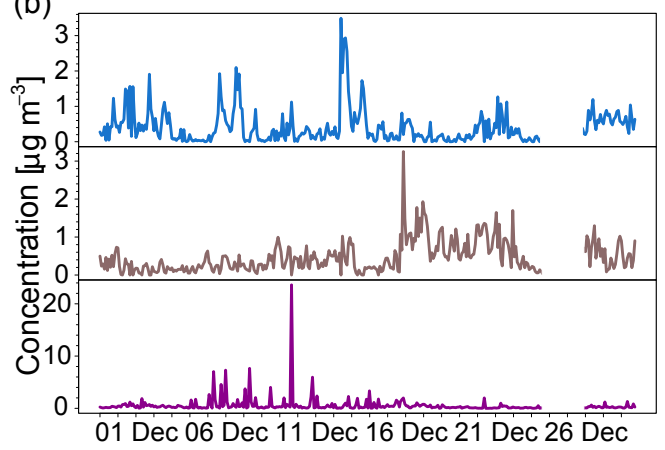

Fig. 5. PMF results for $\mathrm{PM}_{10-2.5}$, (a) factor profiles, from top to bottom: mineral dust, road traffic and de-icing salt. The solid bars (left $y$-axis) represent the amount of each species apportioned to the factor and the blue squares (right $y$-axis) represent the fraction of the total of each species, (b) corresponding time series.

\subsection{Interpretation of PMF results}

\subsubsection{RDI-PMF}

RDI data with 2-h time resolution were used for source apportionment studies with PMF. The relation between observed and predicted time trends and their correlation with time series of additional data (Sect. 3.2.3) were investigated. Profiles were also compared to elemental signatures found in the literature. The factor profiles in Figs. 4, 5 and 6 display the fraction of the profile signal on the left $y$-axis for each factor (the normalization is chosen such that the sum of all elemental signals equals to 1 for each factor) and the frac- tion of the elemental mass concentration on the right $y$-axis (the contributions of one element in all factors sum up to 1 and are depicted as blue squares). If both fraction of profile signal and fraction of elemental mass concentration are high for a certain element it is considered as a specific and strong marker for a source. Plots of the explained variance of PMF calculations for each element can be found in the supplementary material (Figs. S6-S8).

For $\mathrm{PM}_{1-0.1}$ five factors were identified and the profiles of secondary sulfate, wood combustion, road traffic, an industrial factor and local anthropogenic background activities are shown in Fig. 4a. Corresponding time series are shown in Fig. 4b. When the exceptional data during NYE 
(a)

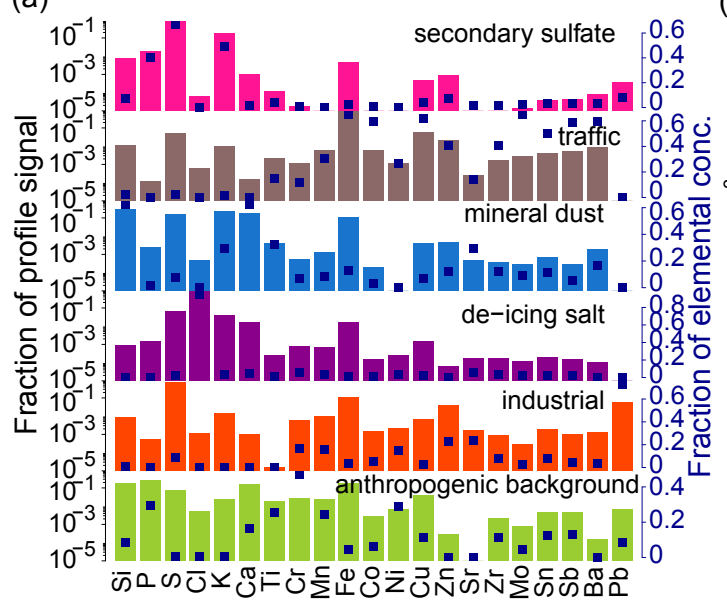

(b)

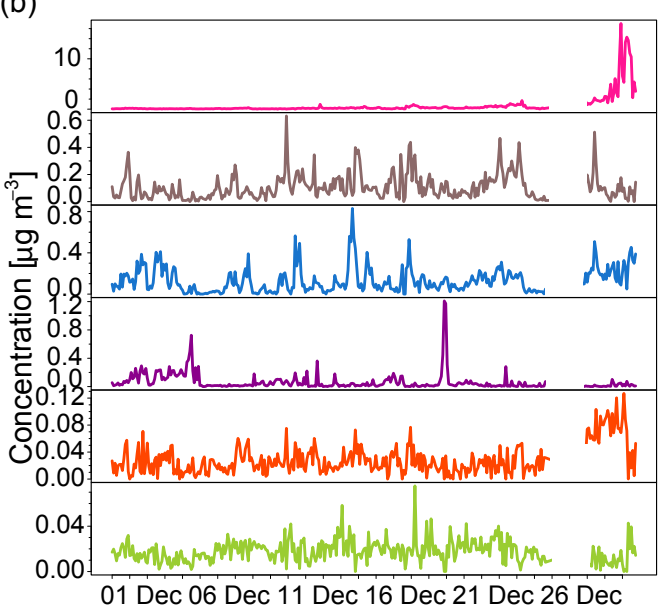

Fig. 6. PMF results for $\mathrm{PM}_{2.5-1}$, (a) factor profiles, from top to bottom: secondary sulfate, road traffic, mineral dust, de-icing salt, industrial and local anthropogenic background. The solid bars (left $y$-axis) represent the amount of each species apportioned to the factor and the blue squares (right $y$-axis) represent the fraction of the total of each species, (b) corresponding time series.

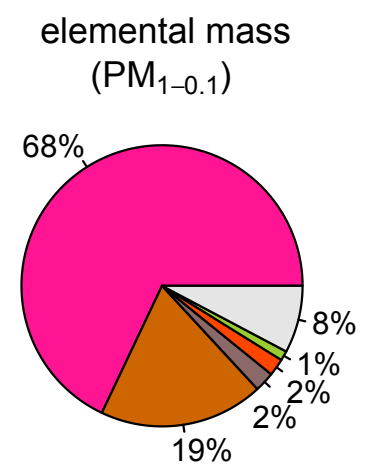

$\begin{array}{ll}\square & \text { secondary sulfate } \\ \square \quad \text { wood combustion related } \\ \square \quad \text { traffic } \\ \square \quad \text { industrial }\end{array}$ elemental mass

$\left(\mathrm{PM}_{2.5-1}\right)$

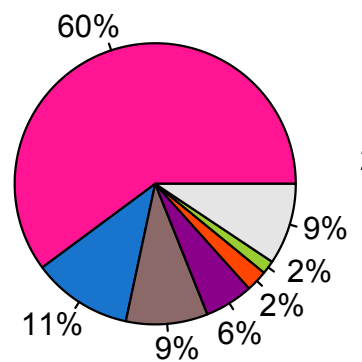

$\square$ anthropogenic background

$\square$ mineral dust

$\square$ de-icing salt

$\square$ unexplained

Fig. 7. Contributions of factors to the measured elemental mass concentration for all three size ranges, when exceptional data during NYE are excluded. The identified factors explain $92 \%, 91 \%$ and $88 \%$ of the elemental mass concentration measured in $\mathrm{PM}_{1-0.1}, \mathrm{PM}_{2.5-1}$ and $\mathrm{PM}_{10-2.5}$, respectively.

are included a distinct fireworks factor was found, which is shown in Fig. 4c and d (all factors for this calculation are shown in Fig. S1). However, to exclude all unusual events and outliers the data set was reduced to the days from 1 December 2008 to 31 December 2008 for all further calculations, excluding NYE data and two unusually high peaks in the lead time series to remove non-representative emissions that are not helpful in describing the pollution status of the city. Secondary sulfate, which is present in secondary and aged aerosol, explains the highest fraction of elemental mass concentration in the fine PM (Fig. 7) and correlates with the time series of total $\mathrm{PM}_{10}$ mass concentrations (Sect. 3.2.3). The high contributions of $\mathrm{P}$ and $\mathrm{K}$ to this factor are attributed to the fact that wood combustion is used for heating purposes in Switzerland and is therefore contributing to this regional source.

$\mathrm{K}$ and $\mathrm{S}$ are typical elements found in emissions from wood combustion and therefore the factor with high contributions of $\mathrm{K}, \mathrm{S}$ and $\mathrm{Pb}$ is attributed to local combustion in open log-wood fires of homeless people. Nriagu and $\mathrm{Pa}$ cyna (1988) found $\mathrm{Cu}, \mathrm{Pb}$ and $\mathrm{Zn}$ in emissions from biomass combustions and Schauer et al. (2001) also found Zn. Interestingly, next to minor contributions of a number of other elements, also $\mathrm{Ti}, \mathrm{V}$ and $\mathrm{Ni}$ contribute to the wood combustion factor. It is further discussed in Sect. 3.2.3. 
(a)

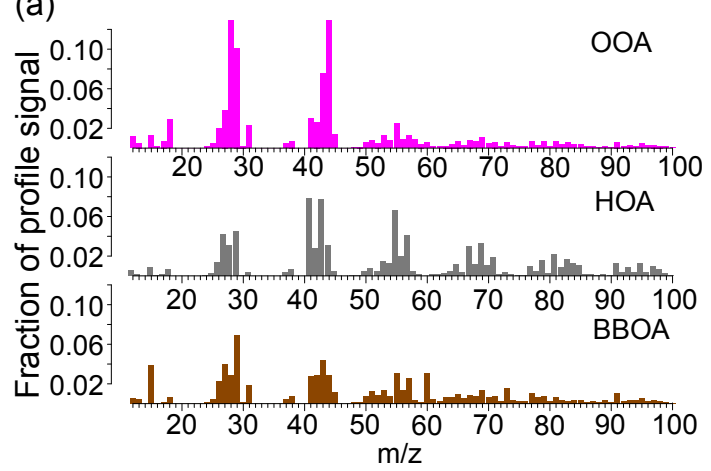

(b)

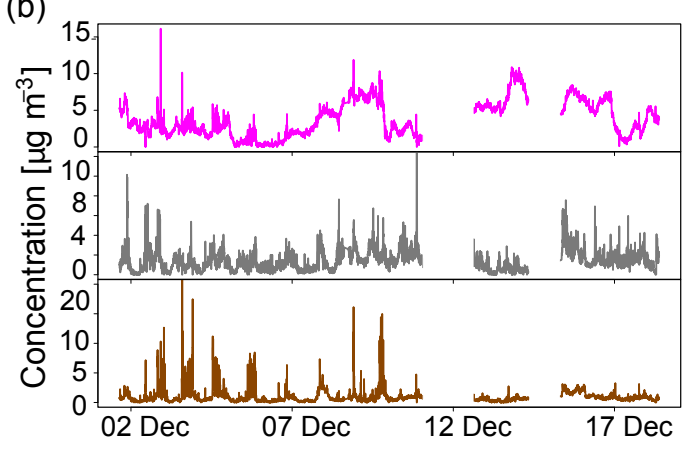

Fig. 8. PMF results for AMS data, (a) factor profiles, from top to bottom: oxygenated (OOA), hydrocarbon-like (HOA) and biomass burning (BBOA) organic aerosol. The solid bars (left $y$-axis) represent the amount of each species apportioned to the factor, (b) corresponding time series.

The factor with high contributions of metals like $\mathrm{Mn}, \mathrm{Fe}$, $\mathrm{Ni}, \mathrm{Cu}, \mathrm{Zn}, \mathrm{Zr}, \mathrm{Mo}, \mathrm{Sn}, \mathrm{Sb}, \mathrm{Ba}$ and $\mathrm{Pb}$ is attributed to a traffic related motor vehicle source since these elements are found in abrasion processes, e.g. from brake pads (Bukowiecki et al., 2009b). At the high temperatures in the lining/rotor interface during braking, vaporization of particles can occur which then end up in the fine mode after condensation (Karanasiou et al., 2009; Salma and Maenhaut, 2006). Furthermore, it can be hypothesized that trains from the nearby main station also play a role in the fine mode since the factor is dominated by iron. However, on a mass basis this traffic contribution in the fine range is very small: it only amounts to $2 \%$ of the elemental mass in $\mathrm{PM}_{1-0.1}$ (Fig. 7).

Furthermore, a local factor of anthropogenic background activities with no clear time series and a factor with mainly contributions of $\mathrm{Zn}$ and $\mathrm{Pb}$ were identified with very low contributions to the fine mode elemental mass in the order of 1 and $2 \%$, respectively. Amato et al. (2010) also found a factor with high mass concentrations of $\mathrm{Zn}, \mathrm{Pb}$ and some $\mathrm{Mn}$ and $\mathrm{Ni}$ in Barcelona and attributed it to industrial emissions. For Zürich industrial emissions play a smaller role. Since Zürich Kaserne is surrounded by different workshops and ateliers and also smaller construction sites, contributions of $\mathrm{Si}, \mathrm{Ca}$ (mainly crustal origin, but also found in gypsum at construction works) and $\mathrm{Ti}$ (included in white paint) from local anthropogenic activities can be expected.

When including the measurement interval coinciding with fireworks during New Year's Eve an additional factor is obtained for $\mathrm{PM}_{1-0.1}$ with a distinct time series shown in Fig. 4d. It explains the highest fraction of the elemental mass concentrations of $\mathrm{Ti}, \mathrm{V}, \mathrm{Sr}$ and $\mathrm{Ba}$ comparing well with findings from Moreno et al. (2007). The explosive material in fireworks is black powder: $\mathrm{KNO}_{3}, \mathrm{~S}$, and $\mathrm{C}$ (not quantified with the RDI-SR-XRF method). Colors originate from metallic additives, such as $\mathrm{Sr}$ (red), $\mathrm{Cu}$ in the form of $\mathrm{C}_{4} \mathrm{H}_{6} \mathrm{As}_{6} \mathrm{Cu}_{4} \mathrm{O}_{16}$ (blue), $\mathrm{Ca}$ compounds such as the chloride and sulfate (orange), $\mathrm{Ti}$ (silvery, grey), $\mathrm{Sr} / \mathrm{Cu}$ (violet), $\mathrm{Ba} / \mathrm{Cl}$

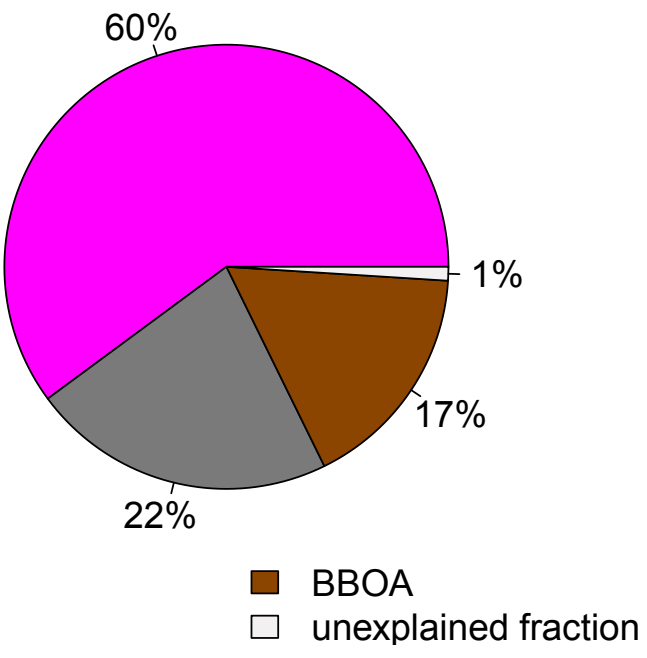

Fig. 9. Contributions of identified factors with AMS-PMF to mass concentration of organic compounds measured with the AMS (from 1 till 18 December 2008).

(green) and $\mathrm{Pb}$ (red) (Moreno et al., 2007, 2010; Godri et al., 2010). One could also expect Sb which is commonly used for glittery effects, but here most of Sb was attributed to brake pads. Elements commonly found in fireworks such as $\mathrm{K}, \mathrm{Ti}, \mathrm{V}, \mathrm{Sr}$ and $\mathrm{Ba}$ exhibit sharp peaks (restricted to the time slot from 31 December 2008, 15:00 LT to 1 January 2009, 09:00 LT) with mass concentrations exceeding up to 200 times the average ambient mass concentrations. These concentrations in the fine mode decreased to a moderate mass concentration only on 3 January 01:00 LT. Weaker peaks are observed for $\mathrm{Si}, \mathrm{P}$ and $\mathrm{Cu}$. The elevated mass concentrations around New Year's Eve are also reflected in the time series of $\mathrm{SO}_{2}, \mathrm{CO}$ and $\mathrm{NO}$.

For the largest size fraction, $\mathrm{PM}_{10-2.5}$, three factors were identified, see Fig. 5. A mineral dust factor consisting mainly of $\mathrm{Al}, \mathrm{Si}, \mathrm{K}, \mathrm{Ca}, \mathrm{Ti}, \mathrm{Fe}$ and $\mathrm{Sr}$ was found. These elements 


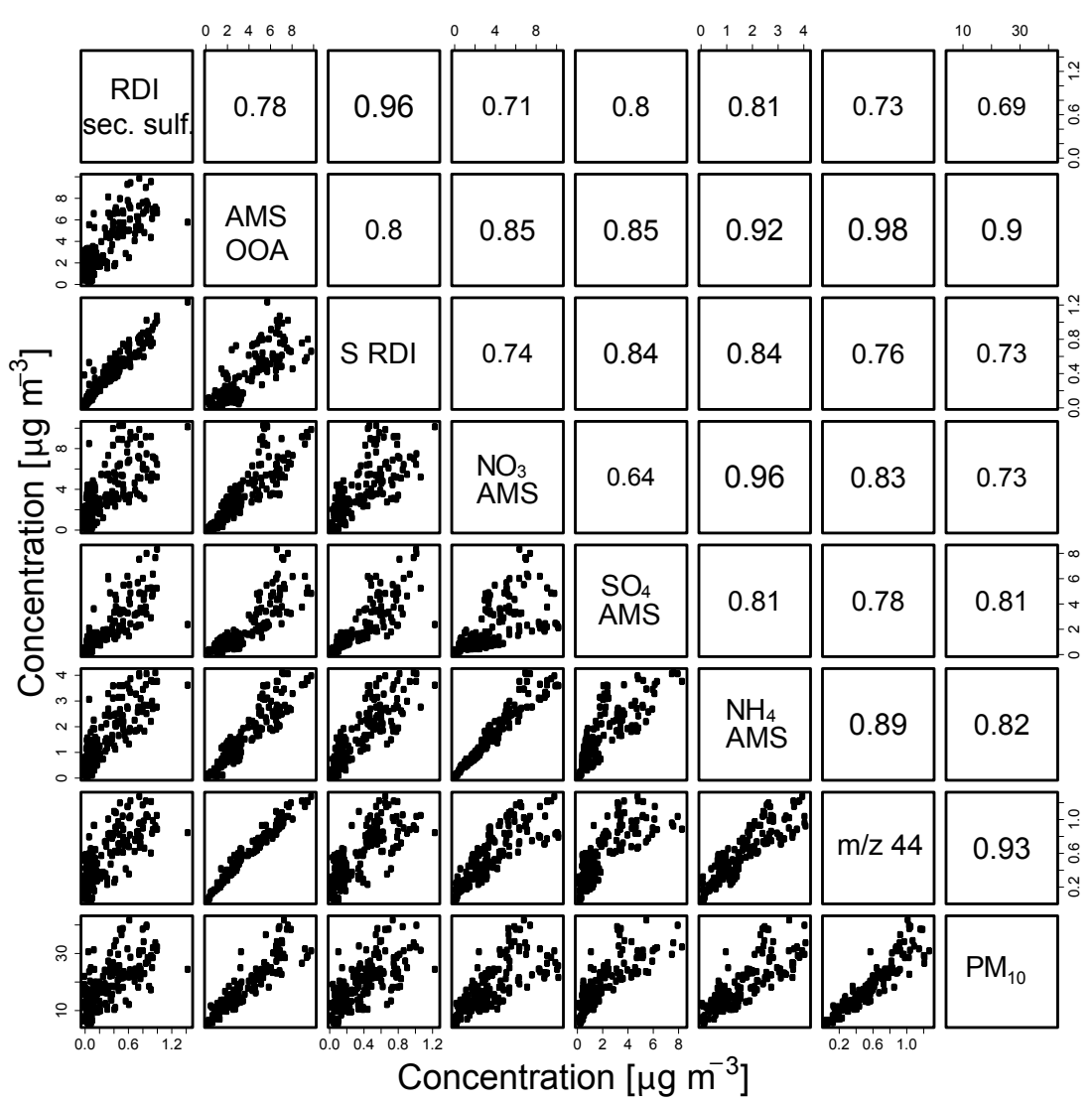

Fig. 10. Matrix of scatter plots showing the pair-wise correlations of the secondary sulfate factor found for PM $1-0.1$ with RDI-PMF, AMSOOA factor, $\mathrm{S}$ measured with $\mathrm{RDI}, \mathrm{NO}_{3}^{-}, \mathrm{SO}_{4}^{2-}, \mathrm{NH}_{4}^{+}, \mathrm{m} / z 44$ measured with AMS and total $\mathrm{PM}_{10}$ mass concentrations (shown are only most relevant species, the ones not shown do not have significant correlation). The panels in the upper right half show the Pearson correlation coefficients and the lower left panels show corresponding data points.

are commonly attributed to soil and terrestrial elements and are present as oxides: $\mathrm{Al}_{2} \mathrm{O}_{3}, \mathrm{SiO}_{2}, \mathrm{~K}_{2} \mathrm{O}, \mathrm{CaO}, \mathrm{TiO}_{2}, \mathrm{Fe}_{2} \mathrm{O}_{3}$ and $\mathrm{SrO}$. This factor contains also contributions of $\mathrm{S}, \mathrm{Mn}$, $\mathrm{Zn}$ and $\mathrm{Ba}$ which were also described to be present in the earth's crust by Rudnick and Gao (2006). There are some constraints on the inter-elemental ratios in crustal material: for silicon and aluminum, it is expected that there is no $\mathrm{Al}$ without $\mathrm{Si}$ unless there is an $\mathrm{Al}$ smelter in the vicinity of the receptor site. On the contrary, there might be $\mathrm{Si}$ without Al (quartz). Rudnick and Gao (2006) found a ratio of 3.8 for $\mathrm{Si} / \mathrm{Al}$ in the upper continental crust. Rahn (1976) found higher $\mathrm{Si} / \mathrm{Al}$ ratios for urban areas (2-4.63) and lower ratios for non-urban areas (1.4-3.19). The $\mathrm{Si} / \mathrm{Al}$ ratio found in Zürich for $\mathrm{PM}_{10-2.5}$ was 2.3. This is also in agreement with the values found by D'Alessandro et al. (2003), which are in the range of 1.9-3.7. However, previous studies (Hueglin et al., 2005) assumed a higher ratio $(\mathrm{Si} / \mathrm{Al}=3.41)$ for the estimation of the Si mass concentration from Al-filter values in Zürich Kaserne. The same road traffic factor as for the fine size range was identified, with the difference that the fractions of elemental contributions of $\mathrm{S}, \mathrm{K}, \mathrm{Si}$ and $\mathrm{Ca}$ are higher for the coarse fraction. The third source is a distinct chlorine factor with some contributions from $\mathrm{S}$ and some crustal elements. It is attributed to de-icing salt used on the roads in wintertime and possibly mixed to a small extent with resuspension of mineral dust or traffic related particles.

$\mathrm{PM}_{2.5-1}$ includes the tail ends of coarse and fine particles and accordingly it is expected that factors similar to those of $\mathrm{PM}_{10-2.5}$ and $\mathrm{PM}_{1-0.1}$ will appear. In fact, a mixture of six aforementioned sources from the other size ranges was identified: fine-mode secondary sulfate, local background activities and industrial as well as coarse-mode road traffic, mineral dust and de-icing salt (Fig. 6). When including NYE data, it was observed that the fire works factor decreases somewhat faster for the intermediate size range, indicating that the life time of $\mathrm{PM}_{1}$ particles in the atmosphere is longer. Not only the time trend of the fire works factor is varying for the different size ranges, there are also small deviations for other factors. This might be due to different mixing mechanisms of particles in differing sizes. 
Pie charts depicting the relative contributions of the identified sources to the respective sum of measured elemental mass of the three size ranges are shown in Fig. 7. Since $\mathrm{Cl}$ contributes the highest amount to the mass of all detected elements in $\mathrm{PM}_{10-2.5}$ (Fig. 3), the de-icing salt factor consistently shows the highest percentage of all factors. Contributions of mineral dust and road traffic factors are in the same order of magnitude in both $\mathrm{PM}_{10-2.5}$ (25 and $28 \%$, respectively) and $\mathrm{PM}_{2.5-1}$ (11 and 9\%, respectively). The secondary sulfate factor presents the largest contribution for the fine and intermediate size range.

\subsubsection{AMS-PMF}

A separate PMF calculation with AMS data yielded a threefactorial solution with oxygenated (OOA), hydrocarbonlike (HOA) and biomass burning (BBOA) organic aerosol. Source profiles are displayed in the right panel of Fig. 8 showing the normalized fraction of the profile signal versus mass-to-charge ratio $(\mathrm{m} / \mathrm{z})$, corresponding time series are shown in the left panel. Calculations were made with the full range of $269 \mathrm{~m} / \mathrm{z}$ 's, but the profiles show only the most abundant elements (up to $m / z$ 100). The factors identified here are in agreement with the same three sources detected by Lanz et al. (2008) in an earlier winter measurement campaign at the same site. However, a hybrid receptor model solved by ME2 including HOA as a priori source was used there, whereas no initial assumptions about sources were made here.

To identify the most appropriate number of factors, PMF was run by varying the number of factors between 2 and 7 (see also the supplementary material). The most reasonable number of factors was determined following the interpretability of the identified factors (according to the methods applied by Lanz et al. (2007) for measurements at the same sampling site) and the criteria of the "uniqueness of the derived factors" as discussed by Allan et al. (2010). Two factors revealed an OOA factor and a mixture of HOA and BBOA. With four and five factors, the OOA factor was split into a component dominated by $m / z, 44$ and 28 and a second one dominated by $\mathrm{m} / \mathrm{z} 29$, while $\mathrm{m} / \mathrm{z}, 29$ mostly disappears from the BBOA mass spectra. Furthermore the time series were not unique anymore, since the new factor dominated by $\mathrm{m} / \mathrm{z} 29$ and the BBOA factor have the same time trend in the beginning of the measurement campaign.

A distinct peak in the profile is found for the OOA factor at $m / z 44$, a signal dominated by the fragment $\mathrm{CO}_{2}^{+}$from di- and poly-carboxylic acid functional groups, representing oxygenated organic aerosol components. Smaller peaks are found for $\mathrm{m} / \mathrm{z} 29$ and for 18 and 28 (proportional to $\mathrm{m} / \mathrm{z} 44$ ). The HOA factor is dominated by $m / z$ 's $27,29,41,43,55,57$, 67 and $69 ; m / z 57$ (butyl, $\mathrm{C}_{4} \mathrm{H}_{9}^{+}$) is a tracer for hydrocarbonlike combustion aerosol (e.g. diesel exhaust). The high peak of $m / z 55$ in HOA might be attributed to food cooking and charbroiling (Mohr et al., 2009; Lanz et al., 2007), since several restaurants are located in the streets close to the measure- ment site and to a lesser extent to plastic burning which could originate from the open fires within Kaserne. The BBOA factor resembles most the time series of $m / z 60$. Mass-to-charge ratios $15,29,60,73,91$ as well as 137 have also been linked to BBOA by Schneider et al. (2006) and Alfarra et al. (2007).

Coefficients of determination $\left(R^{2}\right)$ between the OOA time series and the time series of $\mathrm{SO}_{4}^{2-}, \mathrm{NO}_{3}^{-}, \mathrm{NH}_{4}^{+}$increased with negative FPEAK, reaching maximal values at FPEAK $=-0.6\left(R^{2}=0.69,0.71\right.$ and 0.83 for $\mathrm{SO}_{4}^{2-}, \mathrm{NO}_{3}^{-}$ and $\mathrm{NH}_{4}^{+}$, respectively). In contrast, $R^{2}$ between the HOA time series and the time series of $\mathrm{NO}_{\mathrm{x}}$ was maximal at positive $\operatorname{FPEAK}\left(R^{2}=0.47, \mathrm{FPEAK}=[0.5,0.0]\right)$ and decreased with negative FPEAK $\left(R^{2}=0.39-0.37\right.$, FPEAK $=[-0.1$, $-0.6])$. In a second step, the spectral similarity of AMS-PMF mass spectra with a selection of illustrative reference spectra was determined. The correlation of the OOA spectrum found by Lanz et al. (2008) in winter at the same location and reference OOA spectra from Pittsburgh (Ulbrich et al., 2009; Zhang et al., 2005) and an aged rural reference spectrum (Alfarra et al., 2004), all compiled by Ulbrich et al. (2009), increased with negative FPEAK. The largest correlation of the BBOA and wood burning reference mass spectra was found for negative FPEAK. In contrast to OOA and BBOA, largest correlations with reference mass spectra were found for HOA at positive FPEAK. However $R^{2}$ did not increase as much as with BBOA and OOA, and it changed only slightly presenting always values larger than 0.75 . Due to correlation values (mass spectra and time series) the most reasonable solution was chosen at a negative FPEAK of -0.4 (the OOA time series correlated with the inorganic species measured in the AMS $\left(\mathrm{NO}_{3}^{-}, \mathrm{SO}_{4}^{2-}\right.$ and $\left.\mathrm{NH}_{4}^{+}\right)$, and the highest correlation was found for BBOA and OOA mass spectra with reference mass spectra). Moreover at this FPEAK low $Q / Q_{\exp }$ and low rotational freedom (indicated in PMF through the matrix rotmat) were found.

For all the three factorial solutions the largest organic aerosol fraction was explained by OOA (45-63\%, depending on FPEAK). Lower contributions were observed for HOA $(22-36 \%)$ and BBOA (14-19\%). For the chosen solution, the contributions were OOA $60 \%$, HOA $22 \%$ and BBOA $17 \%$ (Fig. 9). Lanz et al. (2008) found higher values for BBOA in winter at the same site, which can be explained by lower temperatures with average values below zero during that campaign. The high contributions from OOA can be due to winter inversion weather conditions, i.e. stagnant air where accumulation of reaction products of precursors in cold air can be expected.

\subsubsection{Comparison and interpretation of results}

On the basis of all available information, RDI trace elements, RDI-PMF, AMS organics, AMS-PMF, AMS inorganics, gaseous pollutants, total $\mathrm{PM}_{10}$ and meteorological data we try to obtain an increased understanding of the composition of atmospheric pollutants. For this purpose this section 


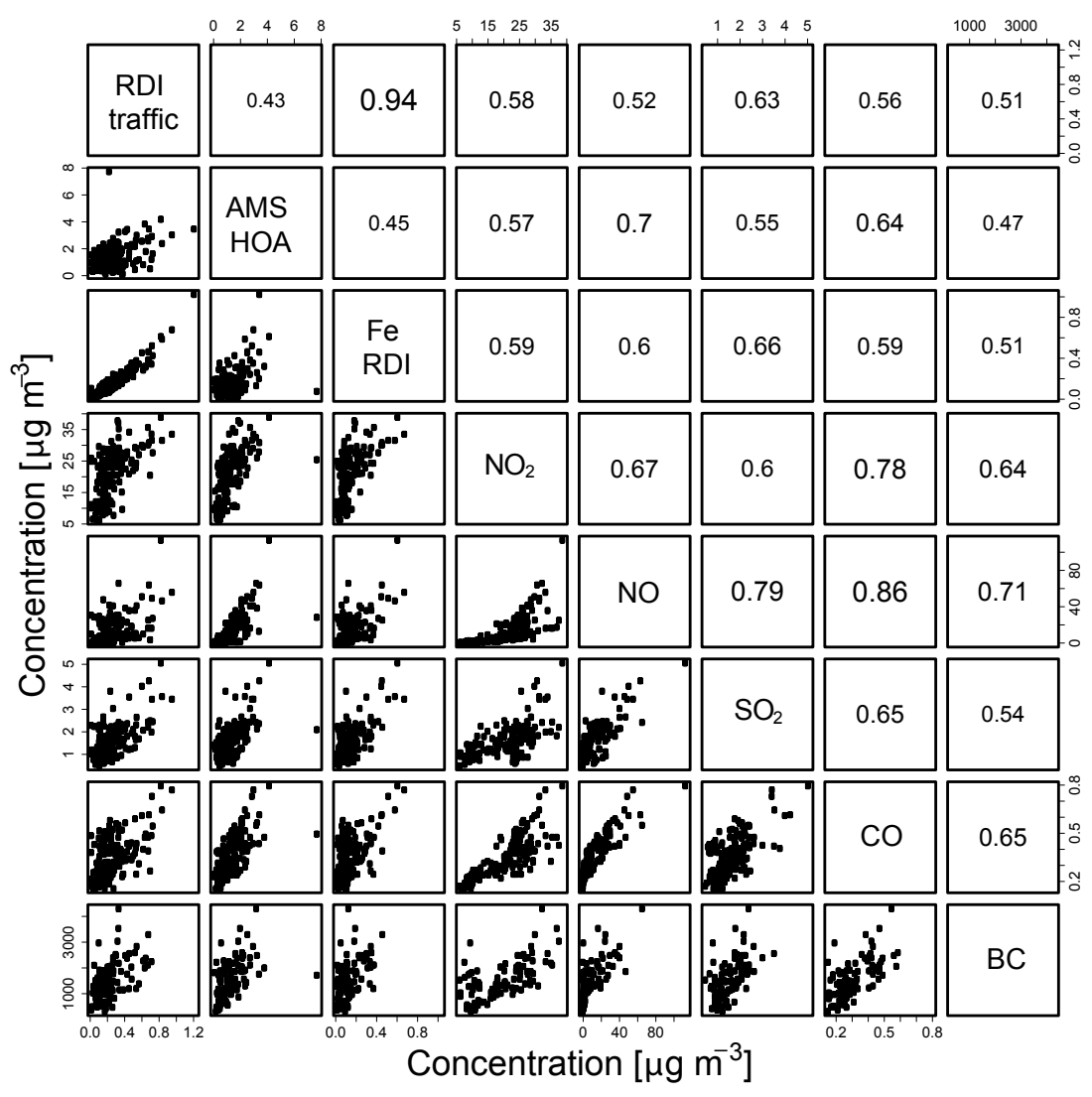

Fig. 11. Matrix of scatter plots showing the pair-wise correlations of the traffic factor found for $\mathrm{PM}_{10-2.5}$ (must abundant in this size range) with RDI-PMF, the AMS-HOA factor, Fe (also $\mathrm{PM}_{10-2.5}$ ) measured with RDI, $\mathrm{NO}_{2}, \mathrm{NO}, \mathrm{SO}_{2}, \mathrm{CO}$ and $\mathrm{BC} \mathrm{PM}_{1}$ mass concentrations (shown are only most relevant species, the ones not shown do not have significant correlation). The panels in the upper right half show the Pearson correlation coefficients and the lower left panels show corresponding data points.

deals with the investigation of correlations of species and the comparison of diurnal variations of obtained factors with those of other tracer species.

AMS measurements of organics, sulfate, ammonium and nitrate in atmospheric aerosols complement the elemental RDI-SR-XRF analysis. Three factors - secondary aerosols (including sulfate extrapolated from $\mathrm{S}$ identified with the RDI), traffic related emissions and emissions from biomass combustion - were detected by both methods, but determined with different tracers. The combination of both methods increases the capability to explain the origin of total atmospheric $\mathrm{PM}_{10}$, since they explain different aspects of emission sources (e.g. RDI: traffic related abrasion particles, AMS: traffic related exhaust particles). The only common species detected by both methods are $\mathrm{S}$ and $\mathrm{K}$ (quantitative measurements of elemental $\mathrm{S}$ and $\mathrm{K}(\mathrm{RDI})$ and $\mathrm{SO}_{4}^{2-}$ (AMS) and qualitative measurements of chemical compounds such as $\mathrm{KCl}$ and $\mathrm{K}_{2} \mathrm{SO}_{4}$ for the AMS). Scatter plots and Pearson correlation coefficients for the three related factors identified with RDI-PMF and AMS-PMF (inorganic secondary sulfate related to OOA, wood combustion related to BBOA and traffic related to $\mathrm{HOA}$ ) and other compounds are shown in Figs. 10, 11 and S10. As part of the continuous measurements performed by the national air pollution monitoring network (NABEL), mass concentrations of nitrogen oxides $\left(\mathrm{NO}_{2}\right.$ and $\left.\mathrm{NO}\right)$, carbon monoxide $(\mathrm{CO})$, sulfur dioxide $\left(\mathrm{SO}_{2}\right)$ and $\mathrm{PM}_{10}$ were recorded with a time resolution of $1 \mathrm{~h}$. These data were also binned into 2-h intervals and are correlated to the factors. The correlation plots reveal a good agreement for secondary sulfate and traffic related factors identified with RDI-PMF and the OOA and HOA factors identified with AMS-PMF, respectively.

Secondary aerosol is formed through atmospheric oxidative processes of gaseous precursors (e.g. $\mathrm{NO}_{\mathrm{x}}, \mathrm{SO}_{2}$, volatile organic compounds (VOCs)) and the subsequent deposition of condensable species (e.g. $\mathrm{H}_{2} \mathrm{SO}_{4}$ ) or low-volatility organics on existing particles. Hence the "source" is a set of atmospheric reactions, not a localized surface emission process and therefore the production rate is sensitive to the efficiency of these reactions. Even though there are also natural sources of $\mathrm{SO}_{2}$ the main source in Switzerland is anthropogenic (e.g. combustion of heating oil and industrial sources). Secondary aerosol formation from $\mathrm{NO}_{\mathrm{x}}, \mathrm{SO}_{2}$ and VOCs proceeds slowly (on the time scale of hours and days). 
(a)

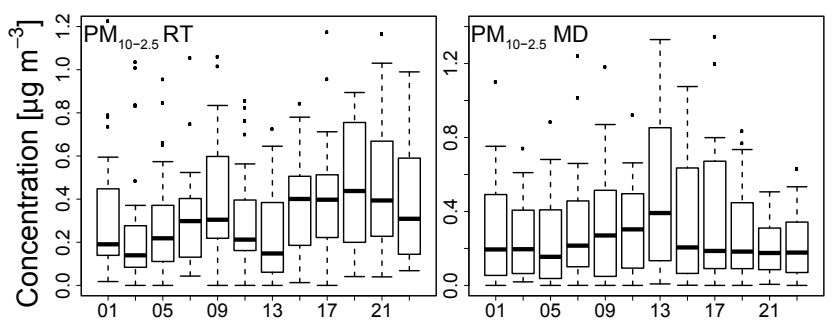

(b)

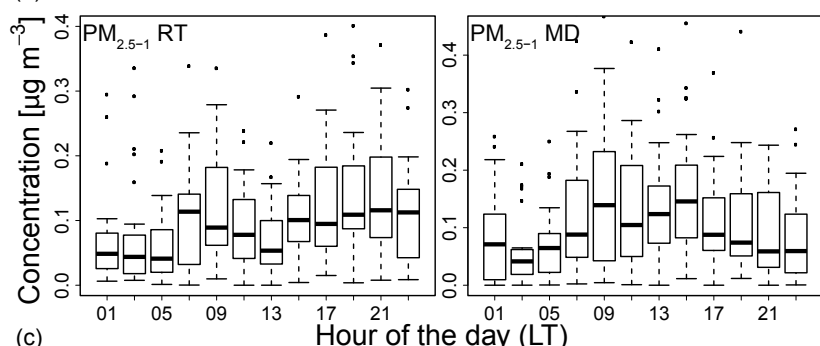

(c) Hour of the day (LT)

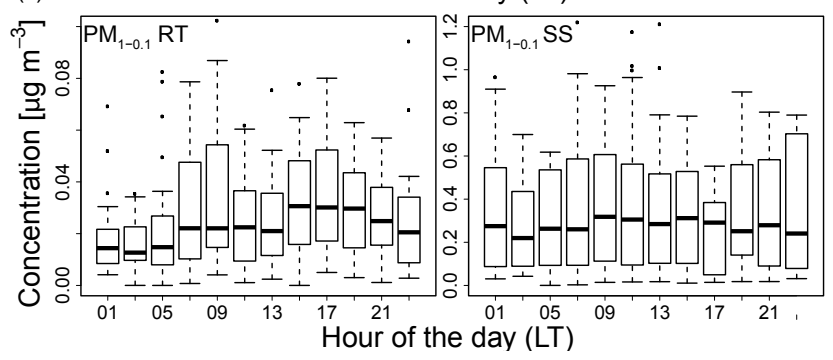

Fig. 12. Average Diurnal variations of the road traffic (RT), mineral dust (MD) and secondary sulfate (SS) factor: (a) shows the diurnal variations of the road traffic (RT) and the mineral dust (MD) factor for $\mathrm{PM}_{10-2.5}$, (b) shows the same for $\mathrm{PM}_{2.5-1}$. (c) shows the variations of the road traffic (RT) and secondary sulfate (SS) factor for $\mathrm{PM}_{1-0.1}$.

Therefore it is reasonable that the secondary sulfate factor does not exhibit a clear diurnal variation (Fig. 12c), indicating a regional rather than a local source. The time trends of OOA and secondary sulfate correlate with the time series of $\mathrm{NO}_{3}^{-}, \mathrm{NH}_{4}^{+}, \mathrm{SO}_{4}^{2-}$ and $m / z, 44$ (Fig. 10) giving further evidence that OOA refers to mostly secondary organic aerosol.

Despite the fact that at many urban locations (Allan et al., 2010) AMS-PMF calculations revealed a cooking factor, no such source could be differentiated for Zürich Kaserne in winter with higher factorial solutions. Restaurants close to Zürich Kaserne are equipped with filters, so that we observe a "contamination" of $\mathrm{m} / \mathrm{z} 55$ in the HOA factor from cooking activities, which is not strong enough to be identified in a separate factor. In contrast, Lanz et al. (2007) found a charbroiling factor for a measurement campaign at the same site in summer, which is mostly attributed to leisure events, like charbroiling, which have no influence in winter.

Regional wood combustion is likely included in the secondary sulfate factor identified with RDI-PMF in the intermediate size range $\mathrm{PM}_{2.5-1}$, because the secondary sulfate factor is characterized through high contributions of $\mathrm{P}$ and $\mathrm{K}$, typical elements found in wood combustion processes. In addition, higher mass concentrations in the secondary sulfate factor were found for $\mathrm{PM}_{1-0.1}$ towards the end of the measurement campaign (no AMS data available). This last period is characterized by temperature inversion conditions, with low temperatures in Zürich Kaserne, no precipitation and thus by a strong increase of total $\mathrm{PM}_{10}$ mass concentrations (Fig. S9). Since secondary aerosol shows an anticorrelation to precipitation, the higher mass concentrations of the secondary sulfate factor in the last measurement period can be explained by the lower precipitation compared to the beginning. The lower temperature would not necessarily increase the sulfur emissions, unless connected to combustion processes for heating purposes. Furthermore, the fast variation and the high peaks in the time trend of the secondary sulfate factor in the second part of the measurement period suggest the presence of an additional local source. Interestingly, the concentration of the secondary sulfate factor in the intermediate size range, increased to an even higher level, but with a time delay of about two days with respect to total $\mathrm{PM}_{10}$. This suggests that the particle size of the accumulation mode increased strongly, such that now the majority of this factor is found in the intermediate size range. This can be due to particle growth under the given meteorological conditions.

Since no correlation of the two biomass burning related factors was found (Fig. S10) they were further investigated. A tracer for freshly emitted wood combustion emissions is levoglucosan $\left(\mathrm{C}_{6} \mathrm{H}_{10} \mathrm{O}_{5}\right)$ which significantly contributes to the wood burning marker $m / z, 60$ in the AMS mass spectra. It dominates the time series of the BBOA factor identified with AMS-PMF. This primary BBOA factor shows no correlation to the wood combustion factor identified with RDI-PMF. In addition, the correlation of the wood combustion factor from RDI-PMF has a correlation coefficient of 0.6 to the OOA AMS factor (compared to $R^{2}=0.78$ of secondary sulfate with OOA), pointing to a regional origin if the regional wood burning gets oxidized and therefore appears to some extent as OOA. Therefore the AMS-BBOA can be interpreted as freshly emitted biomass burning in Zürich Kaserne and nearby, whereas the RDI-PMF secondary sulfate and wood combustion factors each describe parts of the regional wood combustion. Furthermore it might be hypothesized that the RDI can not detect the very fresh components of wood smoke because the cutoff diameter of the lowest size range might be somewhat larger than $100 \mathrm{~nm}$ (rather in the order of $200 \mathrm{~nm}$, see Richard et al., 2010) and therefore the smaller fresh aerosol particles are partially cut off by the RDI, but still seen with the AMS.

The road traffic factor with characteristic elements found in brake pads is present in all three size ranges of the RDI, but contributes most to mass concentrations of trace elements in $\mathrm{PM}_{10-2.5}$. The time trend of this factor shows some correlation with the time series of $\mathrm{NO}_{2}, \mathrm{NO}, \mathrm{CO}, \mathrm{SO}_{2}$ and $\mathrm{BC}$ 


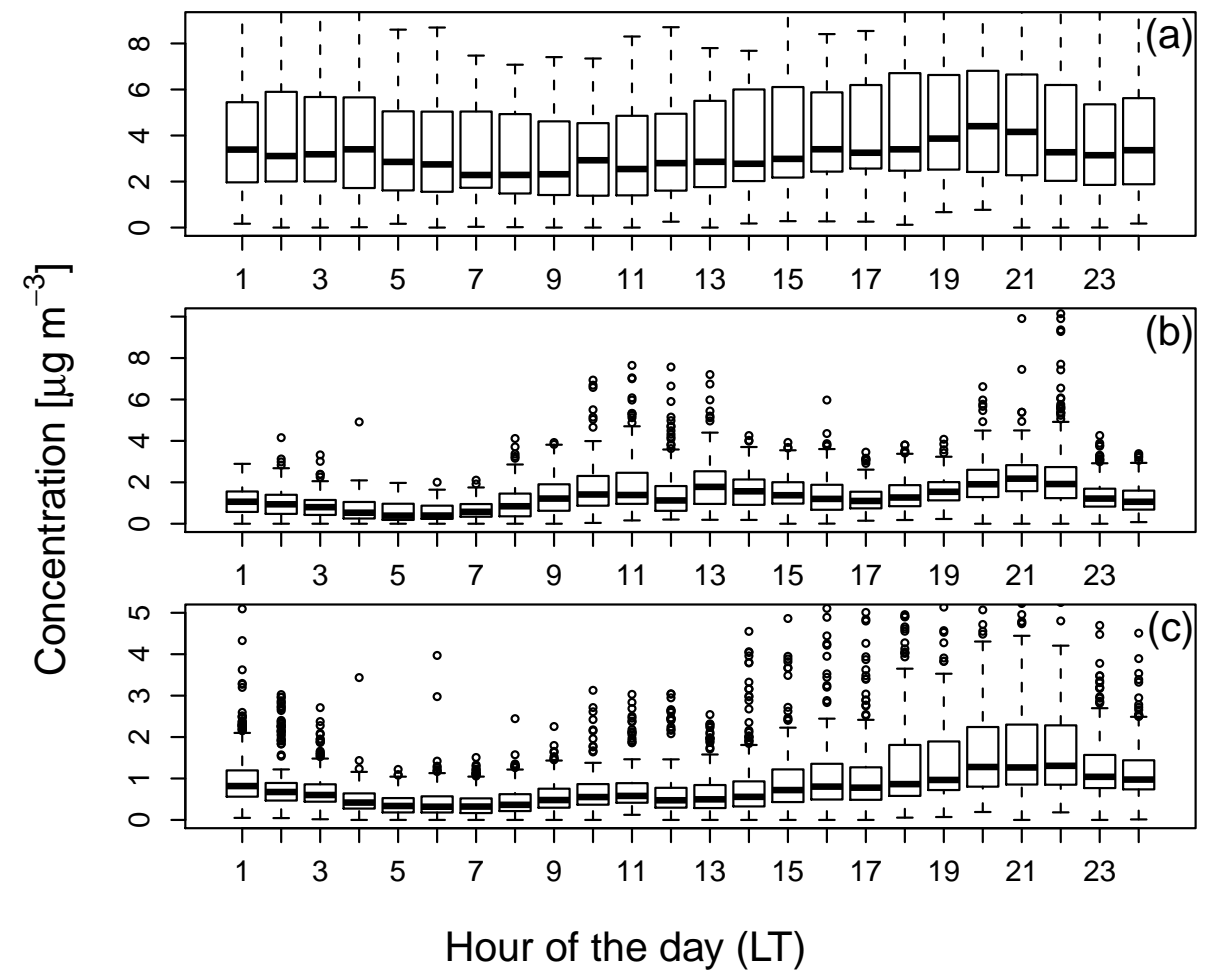

Fig. 13. Average diurnal variations of the OOA (a), HOA (b), and BBOA (c) factors from the AMS-PMF analysis.

(Fig. 11) with Pearson correlation coefficients $R$ in the range of 0.5-0.6. The correlations are shown for the beginning of the campaign (28 November 2008-12 December 2008), where also BC data are available. Accordingly, the nonexhaust traffic related emissions identified through metallic trace elements are to some extent correlated to the exhaust related emissions. HOA has correlation coefficients of 0.57 and 0.7 with $\mathrm{NO}_{2}$ and $\mathrm{NO} . \mathrm{NO}_{\mathrm{x}}$ is formed for example at high temperatures in internal combustion engines through the oxidation of ambient nitrogen, indicating local and fresh sources. Since CO also originates from biomass combustion, one would not expect a perfect correlation of these emissions with the traffic generated ones (Fig. 11, Lanz et al., 2008). Bukowiecki et al. (2010) have analyzed the traffic related emissions (through trace elements, $\mathrm{BC}$ and nitrogen oxides) at a heavily congested street canyon in Zürich and assigned $21 \%$ of the traffic related $\mathrm{PM}_{10}$ emissions to brake wear, $38 \%$ to road dust and $41 \%$ to exhaust emissions. With the here presented PMF analysis restricted to trace elements, only one direct traffic factor - related to brake wear - could be identified. Exhaust emissions are expected to occur with the same time pattern as brake pad abrasion and when AMSPMF measurements are included, the picture is completed by an HOA factor attributed to traffic exhaust emissions.

The mineral/road dust factor found here can also be due to other anthropogenic activities in Zürich Kaserne, for example construction and demolition works. Average diurnal variations of the mineral dust factor are depicted in Fig. 12b, showing elevated mass concentrations during the entire day. Amato et al. (2010) identified a comparable mineral factor on days with street cleaning activities eliminating direct influences of traffic with constantly higher concentrations during the day, but no significant variation within the hours of the day. Increasing day-time concentrations of coarse resuspended dust particles were also observed by Bukowiecki et al. (2002) in the Zürich area with a mobile pollutant measurement laboratory.

The average diurnal variations of the traffic factors for $\mathrm{PM}_{10-2.5}$ and $\mathrm{PM}_{2.5-1}$ are displayed in Fig. 12 and show an elevation in the morning and even higher increase in the early evening. Since the measurement site in Zürich Kaserne is surrounded but not directly influenced by streets, the higher elevation in the evening can be explained by accumulation of traffic related emissions and reduced atmospheric mixing of air parcels. The same is observed for the HOA factor identified with the AMS as shown in Fig. 13. The example of Fe nicely shows the advantage of the size segregation of particles measured with the RDI since Fe in the coarse mode originates both from mineral dust (together with $\mathrm{Al}, \mathrm{Si}$ and $\mathrm{Ca}$ ) and mechanical abrasion from motor vehicles and trains, while there is no considerable contribution from mineral dust on $\mathrm{Fe}$ in the fine mode. In addition, the diurnal variations resulting from the high time resolution allow the distinction of road traffic and other anthropogenic sources. 


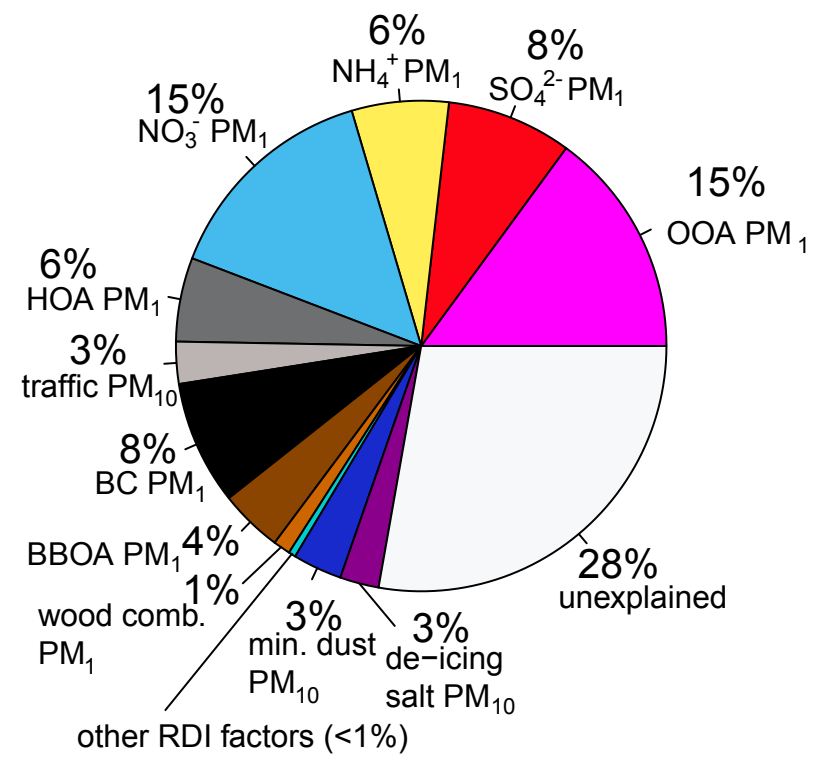

Fig. 14. Contributions of all identified sources with RDI- and AMSPMF plus inorganic compounds measured with the AMS as well as $\mathrm{BC}\left(\mathrm{PM}_{1}\right)$ to total $\mathrm{PM}_{10}$ mass for the interval of simultaneous RDI, AMS and BC measurements. The secondary sulfate factor found with RDI-PMF is omitted to avoid double counting with $\mathrm{SO}_{4}^{2-}$.

Very similar AMS factor profiles were observed in two winter campaigns in Zürich with a mobile laboratory by Mohr et al. (2011). A second AMS in the mobile van measured while driving through busy roads as well as more quiet neighborhoods. The BBOA factor there contains less $m / z$ 60, indicating that the contribution from fresh local emissions of log-wood fires to BBOA in Kaserne is higher than in other parts of the city.

Figure 14 shows the contributions of all identified sources by the RDI and the AMS plus additional inorganic compounds measured by the AMS as well as $\mathrm{BC}\left(\mathrm{PM}_{1}\right)$ to total $\mathrm{PM}_{10}$ mass (interval of simultaneous RDI, AMS and BC measurements). The RDI-PMF was performed with the pure elemental masses but contributions in Fig. 14 are extrapolated to the corresponding oxides. Based on the comparison of the sum of species identified by AMS, RDI and Aethalometer measurements to the total $\mathrm{PM}_{10}$ mass it can be estimated that through the combination of all methods more than $70 \%$ of the total $\mathrm{PM}_{10}$ mass can be apportioned to emission sources. On the basis of this data, it can be estimated that about $70 \%$ of $\mathrm{PM}_{1}$ aerosol is secondary, while for $\mathrm{PM}_{10}$ the fraction of secondary aerosol is smaller (about $60 \%$ ). With the mobile measurements in the city of Zürich contributions of the factors to total measured $\mathrm{PM}_{10}$ were found in the following ranges for different locations: $10-20 \%$ OOA, $4-14 \%$ HOA and $8-15 \%$ BBOA. The same conclusion as here can be drawn: a significant fraction of the $\mathrm{PM}_{1}$ aerosol in downtown Zürich can be attributed to secondary and regional emissions (Zhang et al., 2007).

\section{Conclusions}

Size-segregated trace element measurements with a time resolution of $2 \mathrm{~h}$ were compared to low-time resolution filter data and show good agreement. The application of the PMF model to the size resolved trace element data collected in winter 2008/2009 in Zürich Kaserne, Switzerland resulted in isolating and evaluating the contributions and compositions of eight sources: secondary sulfate, wood combustion, road traffic, fireworks, mineral dust and de-icing road salt, local anthropogenic background activities and an industrial source. On a mass basis, the most important isolated factors affecting the urban background site in winter were found to be consistent with secondary sulfate (accounting for $68 \%$ and $60 \%$ of the trace element mass of $\mathrm{PM}_{1-0.1}$ and $\mathrm{PM}_{2.5-1}$, respectively) and de-icing salt (accounting for 35\% and $6 \%$ of the trace element mass of $\mathrm{PM}_{10-2.5}$ and $\mathrm{PM}_{2.5-1}$, respectively). This is followed by the traffic factor accounting for $28 \%, 9 \%$ and $2 \%$ of the trace element mass of $\mathrm{PM}_{10-2.5}$, $\mathrm{PM}_{2.5-1}$ and $\mathrm{PM}_{1-0.1}$, respectively and mineral dust with $25 \%$ and $11 \%$ of the trace element mass of $\mathrm{PM}_{10-2.5}$ and $\mathrm{PM}_{2.5-1}$, respectively. Furthermore there are minor contributions (in the order of a few percent) of industrial and anthropogenic background sources to $\mathrm{PM}_{2.5-1}$ and $\mathrm{PM}_{1-0.1}$. Calculations were accomplished with both the PMF2 and the ME-2 algorithm which produced equivalent results and showed good agreement. Calculations were performed with varying seed values and no significant difference in the solutions was observed. It has been shown that trace element measurements can add substantial information on the determination of different emissions sources. In addition, organic compounds measured with an AMS were subjected to a separate PMF analysis. Three factors were identified: OOA, HOA and BBOA. The high contribution of OOA to total organics confirms the finding that secondary aerosols dominate the aerosol load in Zürich. Through the combination of RDI and AMS measurements contributions of both exhaust and abrasion related particles could be attributed to traffic emissions. Wood combustion emissions are due to open fires within Kaserne (explained by the local BBOA source identified with AMS measurements) and regional wood combustion from domestic heating (included in the RDI wood combustion and also in the RDI secondary sulfate factor). Since both instruments, AMS and RDI, each only allow for the identification of a part of the total $\mathrm{PM}_{10}$ mass concentration, one analysis can complement the other and the information on composition of identified sources is enhanced. It was shown that PMF can identify a number of sources due to the temporal evolution of elements. A clear advantage is the high time resolution of analyzed samples enabling the identification of sources varying at different hours of the day. This is a considerable improvement compared to 24-h filter analysis, where the attribution to specific sources is possible only on a larger time scale and is mostly based on seasonal variations. 


\section{Supplement related to this article is available online at: http://www.atmos-chem-phys.net/11/8945/2011/ acp-11-8945-2011-supplement.pdf.}

Acknowledgements. Parts of the work were performed at the Swiss Light Source, Paul Scherrer Institut, Villigen, Switzerland. We thank Andreas Jaggi for technical support at the beamline X05DA. Portions of this research were carried out at the light source facility DORIS III at HASYLAB/DESY. DESY is a member of the Helmholtz Association (HGF). We thank Rene Richter for technical support during the measurement campaign and Ingrid Ulbrich et al. (2009) and the US-EPA for providing the user-friendly interfaces to perform calculations for PMF2 and ME-2, respectively.

Edited by: V.-M. Kerminen

\section{References}

Alfarra, M. R., Coe, H., Allan, J. D., Bower, K. N., Boudries, H., Canagaratna, M. R., Jimenez, J. L., Jayne, J. T., Garforth, A., Li, S. M., Worsnop, D. R.: Characterization of urban and regional organic aerosols in the lower Fraser Valley using two aerodyne aerosol mass spectrometers, Atmos. Environ., 38, 57455758, 2004.

Alfarra, M. R., Prévôt, A. S. H., Szidat, S., Sandradewi, J., Weimer, S., Lanz, V. A., Schreiber, D., Mohr, M., and Baltensperger, U.: Identification of the mass spectral signature of organic aerosols from wood burning emissions, Environ. Sci. Technol., 41, 5770-5777, 2007.

Allan, J. D., Jimenez, J. L., Williams, P. I., Alfarra, M. R., Bower, K. N., Jayne, J. T., Coe, H., and Worsnop, D. R.: Quantitative sampling using an Aerodyne aerosol mass spectrometer - 1. Techniques of data interpretation and error analysis, J. Geophys. Res.-Atmos., 108(D3), 4090, doi:10.1029/2002JD002358, 2003.

Allan, J. D., Delia, A. E., Coe, H., Bower, K. N., Alfarra, M. R., Jimenez, J. L., Middlebrook, A. M., Drewnick, F., Onasch, T. B., Canagaratna, M. R., Jayne, J. T., and Worsnop, D. R.: A generalised method for the extraction of chemically resolved mass spectra from Aerodyne aerosol mass spectrometer data, J. Aerosol Sci., 35, 909-922, 2004.

Allan, J. D., Williams, P. I., Morgan, W. T., Martin, C. L., Flynn, M. J., Lee, J., Nemitz, E., Phillips, G. J., Gallagher, M. W., and Coe, H.: Contributions from transport, solid fuel burning and cooking to primary organic aerosols in two UK cities, Atmos. Chem. Phys., 10, 647-668, doi:10.5194/acp-10-647-2010, 2010.

Amato, A., Nava, S., Lucarelli, F., Querol, X., Alastuey, A., Baldasano, J. M., Pandolfi, M.: A comprehensive assessment of PM emissions from paved roads: real-world emission factors and intense street cleaning trials, Sci. Total Environ., 408, 4309-4318, 2010.

BAFU 2007: NABEL Luftbelastung 2007, Report Nr. 370, BAFU, Bern, Switzerland, 2007.

Bukowiecki, N., Dommen, J., Prévôt, A. S. H., Richter, R., Weingartner, E., and Baltensperger, U.: A mobile pollutant measurement laboratory - measuring gas phase and aerosol ambient concentrations with high spatial and temporal resolution, Atmos. Environ., 36, 5569-5579, 2002.
Bukowiecki, N., Hill, M., Gehrig, R., Zwicky, C. N., Lienemann, P., Hegedüs, F., Falkenberg, G., Weingartner, E., and Baltensperger, U.: Trace metals in ambient air: hourly sizesegregated mass concentrations determined by SynchrotronXRF, Environ. Sci. Technol., 39, 5754-5762, 2005.

Bukowiecki, N., Lienemann, P., Zwicky, C. N., Furger, M., Richard, A., Falkenberg, G., Rickers, K., Grolimund, D., Borca, C., Hill, M., Gehrig, R., and Baltensperger, U.: X-ray fluorescence spectrometry for high throughput analysis of atmospheric aerosol samples: the benefits of Synchrotron X-rays, Spectrochim. Acta B, 63, 929-938, 2008.

Bukowiecki, N., Richard, A., Furger, M., Weingartner, E., Aguirre, M., Huthwelker, T., Lienemann, P., Gehrig, R., and Baltensperger, U.: Deposition uniformity and particle size distribution of ambient aerosol collected with a rotating drum impactor, Aerosol Sci. Tech., 43(9), 891-901, 2009a.

Bukowiecki, N., Lienemann, P., Hill, M., Figi, R., Richard, A., Furger, M., Rickers, K., Falkenberg, G., Zhao, Y., Cliff, S. S., Prévôt, A. S. H., Baltensperger, U., Buchmann, B., and Gehrig, R.: Real-world emission factors for antimony and other brake wear related trace elements: size-segregated values for light and heavy duty vehicles, Environ. Sci. Technol., 43, 80728078, 2009b.

Bukowiecki, N., Lienemann, P., Hill, M., Furger, M., Richard, A., Amato, F., Prévôt, A. S. H., Baltensperger, U., Buchmann, B., and Gehrig, R.: PM 10 emission factors for non-exhaust particles generated by road traffic in an urban street canyon and along a freeway in Switzerland, Atmos. Environ., 44, 2330-2340, 2010.

Canagaratna, M. R., Jayne, J. T., Jimenez, J. L., Allan, J. D., Alfarra, M. R., Zhang, Q., Onasch, T. B., Drewnick, F., Coe, H., Middlebrook, A., Delia, A., Williams, L. R., Trimborn, A. M., Northway, M. J., DeCarlo, P. F., Kolb, C. E., Davidovits, P., and Worsnop, D. R.: Chemical and microphysical characterization of ambient aerosols with the aerosol mass spectrometer, Mass Spectrom. Rev., 26, 185-222, 2007.

D’Alessandro, A., Lucarelli, F., Mando, P. A., Marcazzan, G., Nava, S., Prati, P., Valli, G., Vecchi, R., and Zucchiatti, A.: Hourly elemental composition and sources identification of fine and coarse $\mathrm{PM}_{10}$ particulate matter in four Italian towns, J. Aerosol Sci., 34, 243-259, 2003.

DeCarlo, P. F., Kimmel, J. R., Trimborn, A., Northway, M., Jayne, J. T., Aiken, A. C., Gonin, M., Fuhrer, K., Horvath, T., Docherty, K. S., Worsnop, D. R., and Jimenez, J. L.: Fielddeployable, high-resolution, time-of-flight aerosol mass spectrometer, Anal. Chem., 78, 8281-8289, 2006.

Escrig, A., Monfort, E., Celades, I., Querol, X., Amato, F., Minguillón, M. C., and Hopke, P. K.: Application of optimally scaled target factor analysis for assessing source contribution of ambient $\mathrm{PM}_{10}$, J. Air Waste Manage., 59(11), 1296-1307, 2009.

Fittschen, U. and Havrilla, G. J.: Picoliter droplet deposition using a prototype picoliter pipette: control parameters and application in micro X-ray fluorescence, Anal. Chem., 82, 297-306, 2010.

Fittschen, U., Hauschild, S., Amberger, M. A., Lammel, G., Streli, C., Förster, S., Wobrauschek, P., Jokubonis, C., Pepponi, G., Falkenberg, G., and Broekaert, J. A. C.: A new technique for the deposition of standard solutions in total reflection X-ray fluorescence spectrometry (TXRF) using pico-droplets generated by inkjet printers and its applicability for aerosol analysis with SR-TXRF, Spectrochim. Acta B, 61, 1098-1104, 2006. 
Flechsig, U., Jaggi, A., Spielmann, S., Padmore, H. A., and MacDowell, A. A.: The optics beamline at the Swiss light source, Nucl. Instrum. Meth. A, 609, 281-285, 2009.

Gianini, M. F. D., Fischer, A., Gehrig, R., Ulrich, A., Wichser, A., and Hueglin, C.: Comparison of the chemical composition of airborne particulate matter $\left(\mathrm{PM}_{10}\right)$ at different Swiss locations 1998/1999 and 2008/2009, to be submitted, 2011.

Godri, K. J., Green, D. C., Fuller, G. W., Dall'Osto, M., Beddows, D. C., Kelly, F. J., Harrison, R. M., and Mudway, I. S.: Particulate oxidative burden associated with firework activity, Environ. Sci. Technol., 44, 8295-8301, 2010.

Han, J. S., Moon, K. J., Ryu, S. Y., Kim, Y. J., and Perry, K. D.: Source estimation of anthropogenic aerosols collected by a DRUM sampler during spring of 2002 at Gosan, Korea, Atmos. Environ., 39, 3113-3125, 2005.

Huang, S., Rahn, K. A., and Arimoto, R.: Testing and optimizing two factor-analysis techniques on aerosol at Narragansett, Rhode Island, Atmos. Environ., 33, 2169-2185, 1999.

Hueglin, C., Gehrig, R., Baltensperger, U., Gysel, M., Monn, C., and Vonmont, H.: Chemical characterisation of $\mathrm{PM}_{2.5}, \mathrm{PM}_{10}$ and coarse particles at urban, near-city and rural sites in Switzerland, Atmos. Environ., 39, 637-651, 2005.

Jaffrezo, J.-L., Aymoz, G., and Cozic, J.: Size distribution of EC and $\mathrm{OC}$ in the aerosol of Alpine valleys during summer and winter, Atmos. Chem. Phys., 5, 2915-2925, doi:10.5194/acp-52915-2005, 2005.

Jimenez, J. L., Canagaratna, M. R., Donahue, N. M., Prévôt, A. S. H., Zhang, Q., Kroll, J. H., DeCarlo, P. F., Allan, J. D., Coe, H., Ng, N. L., Aiken, A. C., Docherty, K. S., Ulbrich, I. M., Grieshop, A. P., Robinson, A. L., Duplissy, J., Smith, J. D., Wilson, K. R., Lanz, V. A., Hueglin, C., Sun, Y. L., Tian, J., Laaksonen, A., Raatikainen, T., Rautiainen, J., Vaattovaara, P., Ehn, M., Kulmala, M., Tomlinson, J. M., Collins, D. R., Cubison, M. J., Dunlea, E. J., Huffman, J. A., Onasch, T. B., Alfarra, M. R., Williams, P., Bower, K., Kondo, Y., Schneider, J., Drewnick, F., Borrmann, S., Weimer, S., Demerjian, K., Salcedo, D., Cottrell, L., Griffin, R., Takami, A., Miyoshi, T., Hatakeyama, S., Shimono, A., Sun, J. Y., Zhang, Y. M., Dzepina, K., Kimmel, J. R., Sueper, D., Jayne, J. T., Herndon, S. C., Trimborn, A. M., Williams, L. R., Wood, E. C., Middlebrook, A. M., Kolb, C. E., Baltensperger, U., and Worsnop, D. R.: Evolution of organic aerosols in the atmosphere, Science, 326, 1525-1529, 2009.

Karanasiou, A. A., Siskos, P. A., and Eleftheriadis, K.: Assessment of source apportionment by positive matrix factorization analysis on fine and coarse urban aerosol size fractions, Atmos. Environ., 43, 3385-3395, 2009.

Kulmala, M., Asmi, A., Lappalainen, H. K., Carslaw, K. S., Pöschl, U., Baltensperger, U., Hov, Ø., Brenquier, J.-L., Pandis, S. N., Facchini, M. C., Hansson, H.-C., Wiedensohler, A., and O'Dowd, C. D.: Introduction: European Integrated Project on Aerosol Cloud Climate and Air Quality interactions (EUCAARI) - integrating aerosol research from nano to global scales, Atmos. Chem. Phys., 9, 2825-2841, doi:10.5194/acp-92825-2009, 2009.

Lanz, V. A., Alfarra, M. R., Baltensperger, U., Buchmann, B., Hueglin, C., and Prévôt, A. S. H.: Source apportionment of submicron organic aerosols at an urban site by factor analytical modelling of aerosol mass spectra, Atmos. Chem. Phys., 7, 1503-
1522, doi:10.5194/acp-7-1503-2007, 2007.

Lanz, V. A., Alfarra, M. R., Baltensperger, U., Buchmann, B., Hueglin, C., Szidat, S., Wehrli, M. N., Wacker, L., Weimer, S., Caseiro, A., Puxbaum, H., and Prévôt, A. S. H.: Source attribution of submicron organic aerosols during wintertime inversions by advanced factor analysis of aerosol mass spectra, Environ. Sci. Technol., 42, 214-220, 2008.

Lanz, V. A., Prévôt, A. S. H., Alfarra, M. R., Weimer, S., Mohr, C., DeCarlo, P. F., Gianini, M. F. D., Hueglin, C., Schneider, J., Favez, O., D'Anna, B., George, C., and Baltensperger, U.: Characterization of aerosol chemical composition with aerosol mass spectrometry in Central Europe: an overview, Atmos. Chem. Phys., 10, 10453-10471, doi:10.5194/acp-10-10453-2010, 2010.

Lighty, J. S., Veranth, J. M., and Sarofim, A. F.: Combustion aerosols: factors governing their size and composition and implications to human health, J. Air Waste Manage., 50, 1565-1618, 2000.

Mohr, C., Huffman, J. A., Cubison, M. J., Aiken, A. C., Docherty, K. S., Kimmel, J. R., Ulbrich, I. M., Hannigan, M., and Jimenez, J. L.: Characterization of primary organic aerosol emissions from meat cooking, trash burning, and motor vehicles with high-resolution aerosol mass spectrometry and comparison with ambient and chamber observations, Environ. Sci. Technol., 43, 2443-2449, 2009.

Mohr, C., Richter, R., DeCarlo, P. F., Prévôt, A. S. H., and Baltensperger, U.: Spatial variation of chemical composition and sources of submicron aerosol in Zurich during wintertime using mobile aerosol mass spectrometer data, Atmos. Chem. Phys., 11, 7465-7482, doi:10.5194/acp-11-7465-2011, 2011.

Moreno, T., Querol, X., Alastuey, A., Minguillón, M. C., Pey, J., Rodriguez, S., Miró, J. V., Felis, C., and Gibbons, W.: Recreational atmospheric pollution episodes: inhalable metalliferous particles from firework displays, Atmos. Environ., 41, 913-922, 2007.

Moreno, T., Querol, X., Alastuey, A., Amato, F., Pey, J., Pandolfi, M., Kuenzli, N., Bouso, L., Rivera, M., and Gibbons, W.: Effect of fireworks events on urban background trace metal aerosol concentrations: is the cocktail worth the show?, J. Hazard. Mater., 183, 945-949, 2010.

Nriagu, J. O. and Pacyna, J. M.: Quantitative assessment of worldwide contamination of air, water and soils by trace metals, Nature, 333, 134-139, 1988.

Ondov, J. M., Buckley, T. J., Hopke, P. K., Ogulei, D., Parlange, M. B., Rogge, W. F., Squibb, K. S., Johnston, M. V., and Wexler, A. S.: Baltimore supersite: highly time- and sizeresolved concentrations of urban $\mathrm{PM}_{2.5}$ and its constituents for resolution of sources and immune responses, Atmos. Environ., 40, 224-237, 2006.

Paatero, P.: Least squares formulation of robust non-negative factor analysis, Chemometr. Intell. Lab., 37, 23-25, 1997.

Paatero, P.: The multilinear engine - a table-driven least squares program for solving multilinear problems, including the $n$-way parallel factor analysis model, J. Comput. Graph. Stat., 8, 854888, 1999.

Paatero, P.: User's Guide for Positive Matrix Factorization Programs PMF2 and PMF3, University of Helsinki, Helsinki, 2004.

Paatero, P. and Hopke, P.: Discarding or downweighting high-noise variables in factor analytic models, Anal. Chim. Acta, 490, 277 289, 2003. 
Paatero, P. and Tapper, U.: Positive matrix factorization: a nonnegative factor model with optimal utilization of error estimates of data values, Environmetrics, 5, 111-126, 1994.

Polissar, A. V., Hopke, P. K., Paatero, P., Malm, W. C., and Sisler, J. F.: Atmospheric aerosol over Alaska - 2. elemental composition and sources, J. Geophys. Res., 103, 19045-19057, 1998.

Putaud, J. P., Raes, F., Van Dingenen, R., Bruggemann, E., Facchini, M. C., Decesari, S., Fuzzi, S., Gehrig, R., Hueglin, C., Laj, P., Lorbeer, G., Maenhaut, W., Mihalopoulos, N., Müller, K., Querol, X., Rodriguez, S., Schneider, J., Spindler, G., ten Brink, H., Torseth, K., and Wiedensohler, A.: A European aerosol phenomenology-2: chemical characteristics of particulate matter at kerbside, urban, rural and background sites in Europe, Atmos. Environ., 38(16), 2579-2595, 2004.

Querol, X., Viana, M., Alastuey, A., Amato, F., Moreno, T., Castillo, S., Pey, J., de la Rosa, J., Artíñano, B., Salvador, P., García Dos Santos, S., Fernández-Patier, R., Moreno-Grau, S., Negral, L., Minguillón, M. C., Monfort, E., Gil, J. I., Inza, A., Ortega, L. A., Santamaría, J. M., and Zabalza, J.: Source origin of trace elements in PM from regional background, urban and industrial sites of Spain, Atmos. Environ., 41, 7219-7231, 2007.

Querol, X., Pey, J., Minguillón, M. C., Pérez, N., Alastuey, A., Viana, M., Moreno, T., Bernabé, R. M., Blanco, S., Cárdenas, B., Vega, E., Sosa, G., Escalona, S., Ruiz, H., and Artíñano, B.: PM speciation and sources in Mexico during the MILAGRO-2006 Campaign, Atmos. Chem. Phys., 8, 111-128, doi:10.5194/acp8-111-2008, 2008.

Rahn, K.: Silicon and aluminium in atmospheric aerosol: crust-air fractionation?, Atmos. Environ., 10, 597-601, 1976.

Reff, A., Eberly, S. I., and Bhave, P. V.: Receptor modeling of ambient particulate matter data using positive matrix factorization: review of existing methods, J. Air Waste Manage., 57, 146-154, 2007.

Richard, A., Bukowiecki, N., Lienemann, P., Furger, M., Fierz, M., Minguillón, M. C., Weideli, B., Figi, R., Flechsig, U., Appel, K., Prévôt, A. S. H., and Baltensperger, U.: Quantitative sampling and analysis of trace elements in atmospheric aerosols: impactor characterization and Synchrotron-XRF mass calibration, Atmos. Meas. Tech., 3, 1473-1485, doi:10.5194/amt-3-14732010, 2010.

Rudnick, R. L. and Gao, S.: Composition of the continental crust, in: The Crust: Treatise on Geochemistry, Elsevier Science, 3.01, 1-57, 2006.

Salma, I. and Maenhaut, W.: Changes in elemental composition and mass of atmospheric aerosol pollution between 1996 and 2002 in a Central European city, Environ. Pollut., 143, 479-488, 2006.
Schauer, J. J., Kleeman, M. J., Cass, G. R., Simoneit, B. R.: Measurement of emissions from air pollution sources $-3 . \mathrm{C}_{1}-\mathrm{C}_{29}$ organic compounds from fireplace combustion of wood, Environ. Sci. Technol., 35, 1716-1728, 2001.

Schneider, J., Weimer, S., Drewnick, F., Borrmann, S., Helas, G., Gwaze, P., Schmid, O., Andreae, M. O., and Kirchner, U.: Mass spectrometric analysis and aerodynamic properties of various types of combustion-related aerosol particles, Int. J. Mass Spectrom., 258, 37-49, 2006.

Ulbrich, I. M., Canagaratna, M. R., Zhang, Q., Worsnop, D. R., and Jimenez, J. L.: Interpretation of organic components from positive matrix factorization of aerosol mass spectrometric data, Atmos. Chem. Phys., 9, 2891-2918, doi:10.5194/acp-9-2891-2009, 2009.

Viana, M., Kuhlbusch, T. A. J., Querol, X., Alastuey, A., Harrison, R. M., Hopke, P. K., Winiwarter, W., Vallius, M., Szidat, S., Prévôt, A. S. H., Hueglin, C., Bloemen, H., Wåhlin, P., Vecchi, R., Miranda, A. I., Kasper-Giebl, A., Maenhaut, W., and Hitzenberger, R.: Source apportionment of particulate matter in Europe: a review of methods and results, J. Aerosol Sci., 39, 827-849, 2008.

Weingartner, E., Saathoff, H., Schnaiter, M., Streit, N., Bitnar, B., and Baltensperger, U.: Absorption of light by soot particles: determination of the absorption coefficient by means of aethalometers, J. Aerosol Sci., 34, 10, 1445-1463, 2003.

Zhang, Q., Alfarra, M. R., Worsnop, D. R., Allan, J. D., Coe, H., Canagaratna, M. R., and Jimenez, J.: Deconvolution and quantification of hydrocarbon-like and oxygenated organic aerosols based on aerosol mass spectrometry, Environ. Sci. Technol., 39, 4938-4952, 2005.

Zhang, Q., Jimenez, J. L., Canagaratna, M. R., Allan, J. D., Coe, H., Ulbrich, I. M., Alfarra, M. R., Takami, A., Middlebrook, A. M., Sun, Y. L., Dzepina, K., Dunlea, E., Docherty, K., DeCarlo, P. F., Salcedo, D., Onasch, T. B., Jayne, J. T., Miyoshi, T., Shimono, A., Hatakeyama, S., Takegawa, N., Kondo, Y., Schneider, J., Drewnick, F., Borrmann, S. L., Weimer, S., Demerjian, K., Williams, P., Bower, K. N., Behreini, R., Cottrell, L., Griffin, R. J., Rautiainen, J., Sun, J. Y., Zhang, Y. M., and Worsnop, D. R.: Ubiquity and dominance of oxygenated species in organic aerosols in anthropogenically-influenced Northern Hemisphere midlatitudes, Geophys. Res. Lett., 34, L13801, doi:10.1029/2007GL029979, 2007. 